\title{
60. MAGNETIC PROPERTIES OF BASALT SAMPLES FROM DEEP SEA DRILLING PROJECT HOLES 417D AND 418A
}

\author{
Yozo Hamano, Tadashi Nishitani, and Masaru Kono, Geophysical Institute, University of Tokyo, Tokyo 113, Japan
}

\section{INTRODUCTION}

This paper presents the results of magnetic studies on basalt samples recovered from Holes 417D and 418A on Deep Sea Drilling Project Legs 51, 52, and 53. These holes are located on 100-m.y.-old magnetic anomaly $M O$ and penetrated, respectively, 365.5 meters and 548.0 meters into oceanic Layer 2. Studies of the Layer 2 basalts provide useful information on the thickness and the mean intensity of the magnetized layer responsible for the lineated magnetic anomalies. Because of good recovery in these holes, the present samples well represent the upper 500 meters of Layer 2 at the sites.

The magnetic properties reported here are the intensity and inclination of natural remanent magnetization (NRM), the intensity of anhysteretic remanent magnetization (ARM), the median demagnetizing field (MDF) for NRM and ARM, the saturation magnetization, the saturation remanent magnetization, the initial susceptibility, and the thermomagnetic properties and lattice constants of magnetic minerals contained in the basalt samples. In addition to the information carried by individual properties, relations between these parameters provide useful information concerning the mechanisms controlling the magnetic characteristics of the basement layers.

\section{EXPERIMENTAL PROCEDURES}

Standard specimens used in the present study were in the shape of minicores $2.53 \mathrm{~cm}$ in diameter and 2.2 to $2.7 \mathrm{~cm}$ in length. Each minicore was sliced into two disks with nearly equal volumes of about $6 \mathrm{~cm}^{3}$, plus a remaining small chip or chips. NRM intensity and inclination were measured on both disks from each minicore with a Schonstedt SSM-1A spinner magnetometer. The arithmetic mean of the two measurements was adopted as the NRM of each sample. The mean deviations of the two intensity and inclination measurements from the mean values are $5.4 \pm 3.7$ per cent and $6.3 \pm 6.8$ per cent (or $3.7 \pm 5.2^{\circ}$ ), respectively. The initial susceptibility of each disk sample was measured using a commercial bridge (Bison Model 3101) and was corrected for sample volume. The arithmetic mean of the two measurements for each minicore is listed in Table 1 as the initial susceptibility of the sample. The mean deviation from the mean value is $4.5 \pm 5.0$ per cent.

After the above measurements were taken, one disk from each minicore was demagnetized with a peak alternating field (AF) of 1000 Oe using a two-axis tumbler system, while the other disk was preserved for future studies. Anhysteretic remanent magnetization (ARM) was measured on these demagnetized specimens using a peak AF of 1000 Oe and a direct field of $3.5 \mathrm{Oe}$. This value of the direct field was chosen to overcome the effects of the ambient field. For
16 selected samples, stepwise AF demagnetization was carried out to $1000 \mathrm{Oe}$ and the median demagnetizing field (MDF) was determined for both NRM and ARM.

Saturation magnetization was measured using a standard magnetic balance with a strong field of $5000 \mathrm{Oe}$, considered to be enough to saturate these oceanic basalts. The arithmetic mean of the two or three measurements on small chips (about $100 \mathrm{mg}$ ) was adopted as the representative value for each minicore sample, and is listed in Table 1 . The deviation of the individual measurements from the mean value for each sample is $5.0 \pm 4.9$ per cent. After this measurement, the saturation remanent magnetization of the chips was measured by a spinner magnetometer. For a few specimens, variation of the remanent magnetization was monitored for about three days. This indicated that the magnetization was effectively constant for the first 3 hours after removal of the strong field, and then decreased linearly against the logarithm of time. Saturation remanent magnetization was therefore measured within 3 hours for all the samples.

Thermomagnetic analyses were carried out on small chips ( $\sim 100 \mathrm{mg}$ in weight) using the above-mentioned magnetic balance with an applied field of $5000 \mathrm{Oe}$. The specimens were heated and cooled in a vacuum $\left(10^{-4}\right.$ torr) between $20^{\circ} \mathrm{C}$ and $700^{\circ} \mathrm{C}$ at a rate of $600^{\circ} \mathrm{C} / \mathrm{hr}$ to determine the Curie temperatures of the magnetic phase in each sample. For 16 selected samples, magnetic minerals were separated by hand, and lattice constants of the magnetic minerals were determined by X-ray diffraction. The X-ray diffraction experiments were made before and after the thermomagnetic analysis to distinguish between the original magnetic phase and the decomposed or altered phase after heating. For some samples, which had complicated thermomagnetic curves, repeated Curie temperature and lattice constant measurements were made over several heating/cooling cycles.

In addition to these magnetic properties, the density of the samples (room-dried) is listed in Table 1. The density can be used to compare the magnetic properties, since some of these properties were measured per unit volume, while others were measured per unit weight.

\section{RESULTS}

The results of the magnetic property measurements for individual samples are given in Table 1 , and the average properties are summarized in Table 2 . The magnetic properties listed here are NRM intensity $J_{n}$, NRM inclination $I_{n}$, ARM intensity $\mathrm{J}_{\mathrm{a}}$, saturation magnetization $\mathrm{J}_{\mathrm{s}}$, saturation remanent magnetization $\mathrm{J}_{\mathrm{r}}$, initial susceptibility $\chi$, and Curie temperature of the original phase $T_{c}$. The Königsberger ratio, $\mathrm{Q}_{\mathrm{n}}\left(=\mathrm{J}_{\mathrm{n}} / \chi \mathrm{H}\right)$, is also listed in Table 1 for convenience and the averages of the ratios $\mathrm{J}_{\mathrm{r}} / \mathrm{J}_{\mathrm{s}}$ and $\mathrm{J}_{\mathrm{s}} / \mathrm{J}_{\mathrm{a}}$ derived from the above measurements are included in Table 
TABLE 1

Magnetic Measurements for Basement Rocks From Holes 417D and 418A

\begin{tabular}{|c|c|c|c|c|c|c|c|c|c|c|}
\hline $\begin{array}{c}\text { Sample } \\
\text { (Interval in } \mathrm{cm} \text { ) }\end{array}$ & $\begin{array}{l}\text { Depth } \\
\text { (m) }\end{array}$ & $\rho$ & $\mathrm{J}_{\mathrm{n}}$ & $I_{n}$ & $\mathrm{~J}_{\mathrm{a}}$ & $\mathrm{J}_{\mathrm{r}}$ & $\mathbf{J}_{\mathrm{s}}$ & $x$ & $\mathrm{~T}_{\mathrm{c}}$ & $Q_{n}$ \\
\hline \multicolumn{11}{|l|}{ Hole 417D } \\
\hline $26-1,90-91$ & 358.38 & 2.75 & 11.11 & -61.5 & 5.51 & 0.202 & 0.771 & 1.346 & 330 & 16.51 \\
\hline $30-5,123-126$ & 399.61 & 2.72 & 9.34 & -74.0 & 4.10 & 0.126 & 0.457 & 0.994 & 358 & 18.79 \\
\hline $35-5,147-149$ & 443.70 & 2.78 & 9.21 & -67.5 & 6.31 & 0.192 & 0.991 & 2.056 & 342 & 8.96 \\
\hline $37-5,23-25$ & 455.86 & - & - & - & - & 0.190 & 0.798 & - & - & - \\
\hline $39-4,94-96$ & 468.94 & 2.80 & 11.38 & -53.8 & 6.21 & 0.177 & 0.969 & 2.135 & 326 & 10.66 \\
\hline $41-5,96-98$ & 481.45 & 2.87 & 12.84 & -60.4 & 7.45 & 0.179 & 0.896 & 1.296 & 256 & 19.82 \\
\hline $43-4,144-146$ & 499.32 & 2.84 & 2.89 & 75.9 & 5.37 & 0.182 & 1.266 & 2.789 & 317 & 2.07 \\
\hline $45-2,32-34$ & 513.82 & 2.65 & 2.86 & -16.8 & 6.44 & 0.181 & 1.287 & 3.296 & 340 & 1.73 \\
\hline $48-6,58-60$ & 540.08 & 2.72 & 1.76 & 28.3 & 4.13 & 0.177 & 1.278 & 3.437 & 326 & 1.02 \\
\hline $48-7,3-5$ & 541.03 & 2.69 & 1.22 & 60.3 & 4.83 & 0.133 & 1.079 & 3.239 & 325 & 0.75 \\
\hline $49-2,38-40$ & 543.88 & 2.61 & 1.13 & -11.5 & 3.86 & 0.134 & 1.082 & 2.980 & - & 0.76 \\
\hline $54-4,98-100$ & 582.48 & 2.84 & 9.51 & 13.6 & 7.69 & 0.184 & 1.150 & 2.214 & 286 & 8.59 \\
\hline $57-2,87-89$ & 607.87 & 2.75 & 3.76 & 17.9 & 3.34 & 0.139 & 1.083 & 3.154 & 369 & 2.38 \\
\hline $59-3,7-9$ & 626.98 & 2.70 & 4.11 & 30.4 & 5.79 & 0.148 & 1.196 & 3.576 & - & 2.30 \\
\hline $62-3,21-23$ & 644.92 & 2.62 & 5.82 & -26.4 & 3.16 & 0.106 & 0.770 & 1.418 & 374 & 8.21 \\
\hline $64-2,18-20$ & 661.68 & 2.82 & 8.05 & -53.3 & 4.35 & 0.139 & 1.001 & 2.215 & - & 7.27 \\
\hline $64-6,30-33$ & 667.80 & 2.88 & 9.07 & -13.6 & 5.59 & 0.126 & 1.071 & 2.606 & 308 & 6.96 \\
\hline $66-4,144-147$ & 683.94 & - & - & - & - & - & 0.517 & - & 372 & - \\
\hline $67-2,80-83$ & 689.07 & - & - & - & - & 0.118 & 1.030 & - & 303 & - \\
\hline $68-1,17-20$ & 696.17 & 2.87 & 3.01 & 66.6 & 3.33 & 0.101 & 1.355 & 3.213 & - & 1.87 \\
\hline $68-6,83-86$ & 704.33 & 2.91 & 4.27 & 73.6 & 3.40 & 0.072 & 1.267 & 2.999 & 270 & 2.85 \\
\hline $69-1,100-103$ & 706.00 & 2.87 & 1.37 & 41.9 & 3.28 & 0.075 & 1.076 & 2.919 & 270 & 0.94 \\
\hline \multicolumn{11}{|l|}{ Hole 418A } \\
\hline $15-1,85-88$ & 320.85 & 2.79 & 27.69 & 23.4 & - & 0.196 & 0.795 & 1.492 & 303 & 37.12 \\
\hline $16-2,38-41$ & 331.10 & 2.62 & 14.41 & 17.0 & 4.44 & 0.141 & 0.9 & 2.0 & 401 & 13.95 \\
\hline $17-2,81-84$ & 334.81 & .2 .61 & 12.30 & 18.7 & - & 0.125 & 0.835 & 1.832 & - & 13.43 \\
\hline $17-4,19-22$ & 336.69 & 2.76 & 7.13 & 23.0 & 3.89 & 0.100 & 0.832 & 2.110 & 335 & 6.76 \\
\hline $18-3,100-103$ & 343.00 & 2.90 & 3.54 & 21.6 & 3.03 & 0.080 & 1.034 & 2.432 & - & 2.91 \\
\hline $18-5,73-76$ & 345.73 & 2.52 & 4.55 & 26.6 & 2.21 & 0.032 & 0.611 & 1.725 & 376 & 5.28 \\
\hline $19-6,106-109$ & 347.56 & 2.91 & 11.42 & - & - & 0.121 & 0.863 & 1.940 & 380 & 11.77 \\
\hline $19-3,55-59$ & 351.12 & - & - & - & - & 0.131 & 0.763 & - & 280 & - \\
\hline $19-6,14-17$ & 354.72 & 2.93 & 16.59 & 24.5 & 6.58 & 0.150 & 0.894 & 1.528 & 228 & 21.72 \\
\hline $20-4,53-56$ & 361.53 & 2.90 & 3.63 & 20.5 & 3.78 & 0.093 & 1.038 & 2.227 & 223 & 3.26 \\
\hline $20-7,5-8$ & 365.15 & 2.88 & 36.56 & 22.3 & 7.31 & 0.172 & 0.688 & 0.937 & 269 & 78.04 \\
\hline $22-1,90-93$ & 367.90 & 2.74 & 23.22 & 22.0 & 7.13 & 0.159 & 0.531 & 1.023 & 334 & 45.40 \\
\hline $23-1,11-14$ & 375.61 & 2.74 & 12.41 & 30.3 & - & 0.154 & 0.483 & 0.785 & 348 & 31.62 \\
\hline $24-1,30-33$ & 376.30 & 2.66 & 16.95 & 25.4 & 5.80 & 0.147 & 0.734 & 1.748 & 336 & 19.39 \\
\hline $24-1,122-125$ & 377.22 & 2.78 & 19.79 & 28.5 & 4.95 & 0.180 & 0.884 & 1.980 & 349 & 16.96 \\
\hline $25-1,9-12$ & 381.58 & - & - & - & - & 0.126 & 0.943 & - & 310 & - \\
\hline $25-1,20-23$ & 381.67 & 2.76 & 18.06 & 25.9 & 4.85 & 0.153 & 0.835 & 2.197 & 347 & 16.44 \\
\hline $25-1,39-42$ & 381.84 & 2.76 & 12.59 & 30.2 & 4.23 & 0.141 & 0.839 & 2.229 & 338 & 11.30 \\
\hline $25-1,50-53$ & 381.93 & - & - & - & - & 0.148 & 0.915 & - & 310 & - \\
\hline $25-1,61-64$ & 382.02 & 2.81 & 4.86 & 30.7 & 4.87 & 0.135 & 0.957 & 2.270 & 317 & 4.28 \\
\hline $25-1,72-75$ & 382.12 & - & - & - & - & 0.128 & 0.497 & - & 362 & - \\
\hline $25-2,7-10$ & 382.85 & 2.71 & 26.24 & 29.7 & 6.29 & 0.168 & 0.703 & 1.528 & - & 34.35 \\
\hline $25-2,15-18$ & 382.92 & 2.67 & 11.14 & 31.9 & - & 0.065 & 0.308 & 0.712 & 349 & 31.29 \\
\hline $25-2,96-99$ & 383.62 & 2.63 & 5.51 & 22.0 & - & 0.132 & 1.006 & 1.948 & - & 5.66 \\
\hline $26-1,104-107$ & 385.54 & 2.84 & 12.50 & 18.9 & 6.09 & 0.134 & 0.882 & 1.912 & 270 & 13.08 \\
\hline $26-4,21-24$ & 389.21 & 2.70 & 10.81 & 26.9 & - & 0.171 & 0.926 & 1.685 & - & 12.83 \\
\hline $26-4,36-39$ & 389.36 & 2.64 & 16.29 & 27.3 & 5.59 & 0.142 & 0.658 & 1.988 & 358 & 16.39 \\
\hline $27-1,41-44$ & 393.91 & 2.69 & 16.99 & 17.0 & 6.52 & 0.180 & 0.992 & 2.707 & 353 & 12.55 \\
\hline $27-2,75-78$ & 395.75 & - & - & - & - & - & 0.746 & - & 352 & - \\
\hline $27-2,79-81$ & 395.79 & 2.61 & 16.20 & 32.8 & 6.30 & 0.216 & 0.745 & 1.961 & 349 & 16.52 \\
\hline $29-1,75-78$ & 412.25 & 2.35 & 6.03 & 34.3 & 3.11 & - & - & 0.874 & - & 13.80 \\
\hline $30-1,16-19$ & 414.66 & 2.72 & 26.55 & 22.2 & 6.59 & 0.192 & 0.880 & 1.717 & 349 & 30.93 \\
\hline $30-2,127-130$ & 417.27 & 2.77 & 21.68 & 16.8 & 5.34 & 0.132 & 0.763 & 1.675 & - & 25.89 \\
\hline $33-1,39-42$ & 440.36 & 2.69 & 12.68 & 15.0 & 6.02 & 0.167 & 0.789 & 2.050 & 354 & 12.37 \\
\hline $33-3,122-125$ & 443.92 & 2.79 & 18.02 & 14.8 & 5.43 & 0.152 & 0.813 & 1.849 & 416 & 19.49 \\
\hline $33-3,130-133$ & 444.00 & 2.77 & 16.41 & 19.8 & 5.52 & 0.127 & 0.739 & 2.116 & 364 & 15.51 \\
\hline $34-1,93-96$ & 449.93 & 2.76 & 8.89 & 24.4 & 3.75 & 0.136 & 0.797 & 2.322 & 340 & 7.66 \\
\hline & & 2.66 & 7.86 & 23.0 & 3.82 & 0.100 & 0.42 & 0.929 & - & 16.92 \\
\hline $36-2,100-103$ & 469.50 & 2.69 & 4.25 & 26.0 & 4.12 & 0.073 & 0.275 & 0.597 & 367 & 14.24 \\
\hline $36-2,116-119$ & 469.61 & 2.72 & 13.82 & 20.6 & 5.28 & 0.126 & 0.719 & 1.875 & 358 & 14.74 \\
\hline $36-3,31-34$ & 470.31 & 2.64 & 8.71 & 18.8 & 3.96 & 0.087 & 0.501 & 1.494 & 345 & 11.66 \\
\hline $36-3,43-46$ & 470.43 & 2.58 & 4.79 & 19.5 & 3.87 & 0.084 & 0.339 & 0.758 & 380 & 12.64 \\
\hline
\end{tabular}


TABLE 1 - Continued

\begin{tabular}{|c|c|c|c|c|c|c|c|c|c|c|}
\hline $\begin{array}{c}\text { Sample } \\
\text { (Interval in } \mathrm{cm} \text { ) }\end{array}$ & $\begin{array}{l}\text { Depth } \\
(\mathrm{m})\end{array}$ & $\rho$ & $\mathrm{J}_{\mathrm{n}}$ & $I_{n}$ & $\mathrm{~J}_{\mathrm{a}}$ & $J_{r}$ & $\mathrm{~J}_{\mathrm{s}}$ & $x$ & $\mathrm{~T}_{\mathrm{c}}$ & $\mathrm{Q}_{\mathrm{n}}$ \\
\hline $36-4,47-50$ & 471.97 & 2.83 & 19.62 & 23.0 & 7.10 & 0.166 & 0.877 & 1.655 & 292 & 23.71 \\
\hline $36-4,128-131$ & 472.78 & 2.54 & 4.41 & 20.7 & 3.55 & 0.086 & 0.359 & 0.755 & 380 & 11.68 \\
\hline $36-4,131-134$ & 472.81 & 2.48 & 10.09 & 23.7 & 2.29 & 0.077 & 0.533 & 1.173 & 380 & 17.20 \\
\hline $37-1,46-49$ & 476.46 & 2.50 & 2.92 & 18.7 & 2.72 & - & 0.296 & 1.050 & 416 & 5.56 \\
\hline $38-1,54-57$ & 480.04 & 2.59 & 7.58 & 26.2 & 4.45 & 0.081 & 0.363 & 1.130 & 368 & 13.42 \\
\hline $38-2,116-119$ & 482.16 & 2.70 & 11.71 & 26.7 & 5.29 & 0.123 & 0.525 & 1.323 & - & 17.70 \\
\hline $38-3,133-135$ & 483.83 & 2.67 & 14.29 & 25.0 & 4.72 & 0.121 & 0.849 & 2.381 & 363 & 12.00 \\
\hline $38-5,99-102$ & 486.49 & 2.51 & 6.77 & 25.4 & 3.81 & 0.110 & 0.785 & 2.496 & 356 & 5.43 \\
\hline $39-1,36-39$ & 488.86 & 2.76 & 11.44 & 25.3 & 3.99 & 0.132 & 0.704 & 1.555 & - & 14.71 \\
\hline $40-2,65-68$ & 498.15 & 2.71 & 17.06 & 16.7 & 5.41 & 0.126 & 0.612 & 1.704 & 389 & 20.02 \\
\hline $41-3,81-83$ & 502.31 & 2.77 & 19.02 & -7.5 & 5.02 & 0.139 & 0.675 & 1.738 & 354 & 21.89 \\
\hline $42-1,88-90$ & 508.38 & 2.38 & 0.57 & -40.9 & 0.93 & - & - & 0.146 & - & 7.81 \\
\hline $43-2,98-101$ & 518.98 & 2.81 & 20.51 & -32.6 & 7.62 & 0.166 & 0.729 & 1.041 & - & 39.40 \\
\hline $43-3,38-41$ & 528.88 & 2.76 & 17.64 & -35.8 & 5.12 & 0.138 & 0.433 & 0.641 & 336 & 55.04 \\
\hline $46-1,129-132$ & 544.79 & 2.91 & 19.30 & -35.0 & 7.50 & 0.178 & 0.737 & 1.104 & 251 & 34.96 \\
\hline $46-3,8-10$ & 546.58 & 2.82 & 20.88 & -35.0 & 7.68 & 0.179 & 0.678 & - & - & - \\
\hline $47-2,4-6$ & 554.04 & 2.84 & 14.64 & -30.6 & 4.63 & 0.161 & 0.867 & 1.802 & 331 & 16.25 \\
\hline $48-4,120-123$ & 567.20 & 2.85 & 19.39 & -28.3 & 7.11 & 0.205 & 0.835 & 1.247 & - & 26.29 \\
\hline $49-1,21-23$ & 570.69 & - & - & - & - & 0.171 & 0.635 & - & 305 & - \\
\hline $50-3,130-132$ & 577.80 & 2.82 & 21.23 & - & 7.29 & 0.177 & 0.781 & 1.272 & 265 & 33.38 \\
\hline $51-2,98-100$ & 585.38 & 2.80 & 22.7 & -23.5 & - & 0.181 & 0.753 & 0.934 & - & 48.69 \\
\hline $53-3,21-23$ & 604.81 & 2.79 & 12.52 & -17.0 & 4.77 & 0.154 & 0.914 & 1.909 & 353 & 13.12 \\
\hline $55-5,31-33$ & 626.14 & 2.82 & 14.31 & 45.8 & - & 0.106 & 1.064 & 2.853 & 376 & 10.03 \\
\hline $57-6,4-6$ & 646.54 & 2.88 & 11.97 & -13.0 & 5.64 & 0.152 & 1.149 & 3.149 & - & 7.60 \\
\hline $63-2,11-13$ & 691.22 & 2.61 & 12.90 & -22.2 & 5.23 & 0.155 & 1.481 & 4.318 & 394 & 5.98 \\
\hline $66-6,132-134$ & 723.42 & 2.83 & 5.05 & -44.7 & 4.01 & 0.109 & 1.146 & 3.266 & - & 3.09 \\
\hline $68-2,98-100$ & 731.58 & - & - & - & - & 0.208 & 1.180 & - & 358 & - \\
\hline $72-1,105-107$ & 759.85 & 2.79 & 15.12 & -70.9 & - & 0.161 & 0.874 & 2.340 & 392 & 12.92 \\
\hline $77-2,22-24$ & 794.82 & 2.88 & 0.72 & -62.0 & 2.61 & 0.070 & 1.663 & 4.531 & 374 & 0.32 \\
\hline $79-7,46-48$ & 820.80 & 2.89 & 4.41 & -59.6 & 5.59 & & & 3.647 & - & 2.42 \\
\hline $80-2,90-92$ & 823.88 & - & - & - & - & 0.091 & 1.915 & - & 330 & - \\
\hline $80-3,67-69$ & 825.13 & 2.88 & 10.02 & & 4.96 & & 1.240 & 3.052 & 358 & 6.57 \\
\hline $84-3,137-139$ & 848.86 & 2.93 & 2.63 & -64.3 & 2.82 & 0.083 & 0.985 & 2.645 & 303 & 1.99 \\
\hline $86-4,108-110$ & 865.08 & 2.75 & 16.56 & -34.5 & 7.49 & 0.147 & 0.792 & 1.873 & 441 & 17.68 \\
\hline
\end{tabular}

Note: $\rho$ :density for room-dried samples, $\mathrm{g} / \mathrm{cm}^{3} ; \mathrm{J}_{\mathrm{n}}$ : intensity of natural remanent magnetization (NRM), $10^{-3} \mathrm{emu} / \mathrm{cm}^{3} ; \mathrm{I}_{\mathrm{n}}$ : inclination of NRM, degrees; $\mathrm{J}_{\mathrm{a}}$ :intensity of anhysteretic remanent magnetization (ARM), $10^{-3} \mathrm{emu} / \mathrm{cm}^{3} ; \mathrm{J}_{\mathrm{r}}$ :saturation remanent magnetization, emu/g; $\mathrm{J}_{\mathrm{s}}$ : saturation magnetization, emu/g; $\mathrm{x}$ : initial susceptibility, $10^{-3}$ Gauss $/ \mathrm{Oe} ; \mathrm{T}_{\mathrm{c}}:$ Curie temperature, ${ }^{\circ} \mathrm{C}$; $\mathrm{Q}_{\mathrm{n}}:$ Königsberger ratio, $\mathrm{J}_{\mathrm{n}} / \mathrm{x} \mathrm{H}$.

2. In Table 1, two samples (Sample 418A 29-1, 75-78 cm and Sample 418A 42-1, 88-90 cm) are breccia and one sample (Sample 418A $80-3,67-69 \mathrm{~cm}$ ) is a basalt dike obtained in the lower part of Hole 418A. All the other samples are basalts from massive flows or pillows. Histograms of the observed values of the magnetic properties listed in Table 1 are shown in Figure 1. The results of each magnetic property measurement are summarized separately in the following.

\section{NRM Intensity $J_{n}$ and Inclination $\mathbf{I}_{\mathbf{n}}$}

The NRM intensities in the present samples vary from $0.72 \times 10^{-3}$ to $36.6 \times 10^{-3} \mathrm{emu} / \mathrm{cm}^{3}$, a range of about two orders of magnitude (Figure 1a). Such wide variations in NRM intensity are commonly observed in DSDP basalts and in other oceanic basalts (cf. Lowrie, 1974; Marshall, 1978 ). But the mean value of $11.85 \times 10^{-3} \mathrm{emu} / \mathrm{cm}^{3}$ (arithmetic mean) or $9.10 \times 10^{-3} \mathrm{emu} / \mathrm{cm}^{3}$ (geometric mean) is much higher than the previously reported values of DSDP samples. It is comparable to, or even higher than, the values observed in dredge-haul samples (Lowrie [1974] reported geometric means of $2.37 \times 10^{-3} \mathrm{emu} / \mathrm{cm}^{3}$ on 107 DSDP samples and $5.37 \times 10^{-3} \mathrm{emu} / \mathrm{cm}^{3}$ on 309 dredged samples). The NRM intensities of two breccia samples are $6.03 \times 10^{-3}$ $\mathrm{emu} / \mathrm{cm}^{3}$ (Section 29-1) and $0.57 \times 10^{-3} \mathrm{emu} / \mathrm{cm}^{3}$ (Section $42-1)$, respectively, and the dike sample (80-3) has a value of $10.0 \times 10^{-3} \mathrm{emu} / \mathrm{cm}^{3}$. These values appear not that much different from those of other basalt samples.

Because we think the number of samples in the present investigation is not large enough to determine the variation of the NRM, and other magnetic properties in each cooling unit, we mainly discuss the difference of the properties between massive flows and pillows. The arithmetic and geometric means of pillow basalts and massive flows are compared in Table 2 for Holes 417D and 418A. As evident from the table, pillow basalts have larger NRM intensities than basalts from massive flows in each hole; between the holes there are also differences and these obscure those between pillows and massive flows (Figure 1a). As in previous DSDP holes, we did not observe overall variation of the intensity with depth in pillow basalts. Massive flows from the lower part of the holes apparently have lower in- 
TABLE 2

Average Magnetic Properties of Basalts

\begin{tabular}{lccccc}
\hline & \multicolumn{2}{c}{ Hole 417D } & \multicolumn{2}{c}{ Hole 418A } & Magnetic \\
Properties & Pillows & Massive Flows & Pillows & Massive Flows & Total \\
\hline $\mathrm{J}_{\mathrm{n}}, 10^{-3} \mathrm{emu} / \mathrm{cm}^{3}$ & $8.00 \pm 3.38(11)$ & $3.09 \pm 2.65(8)$ & $14.46 \pm 6.19(48)$ & $11.09 \pm 9.02(17)$ & $11.85 \pm 7.26(84)$ \\
& 7.21 & 2.41 & 12.87 & 7.79 & 9.19 \\
$\mathrm{~J}_{\mathrm{a}}, 10^{-3} \mathrm{emu} / \mathrm{cm}^{3}$ & $5.49 \pm 1.55(11)$ & $4.22 \pm 0.93(8)$ & $5.23 \pm 1.35(42)$ & $4.71 \pm 1.79(13)$ & $5.07 \pm 1.45(74)$ \\
& 5.27 & 4.14 & 5.05 & 4.38 & 4.85 \\
$\mathrm{~J}_{\mathrm{r}}, \mathrm{emu} / \mathrm{g}$ & $0.16 \pm 0.03(13)$ & $0.12 \pm 0.04(8)$ & $0.14 \pm 0.04(52)$ & $0.12 \pm 0.04(19)$ & $0.14 \pm 0.04(92)$ \\
& 0.16 & 0.11 & 0.14 & 0.11 & 0.13 \\
$\mathrm{~J}_{\mathrm{s}}, \mathrm{emu} / \mathrm{g}$ & $0.92 \pm 0.24(14)$ & $1.18 \pm 0.12(8)$ & $0.75 \pm 0.24(54)$ & $0.96 \pm 0.37(19)$ & $0.85 \pm 0.29(95)$ \\
& 0.89 & 1.18 & 0.71 & 0.90 & 0.80 \\
$\mathrm{x}, 10^{-3} \mathrm{G} / \mathrm{Oe}$ & $2.16 \pm 0.87(11)$ & $3.02 \pm 0.27(8)$ & $1.76 \pm 0.75(47)$ & $2.06 \pm 0.93(17)$ & $2.00 \pm 0.85(83)$ \\
& 1.99 & 3.01 & 1.61 & 1.88 & 1.82 \\
$\mathrm{Q}_{\mathrm{n}},=\mathrm{J}_{\mathrm{n}} / \mathrm{xH}$ & $9.57 \pm 6.43(11)$ & $2.15 \pm 2.08(8)$ & $18.72 \pm 11.41(47)$ & $16.29 \pm 19.85(17)$ & $15.41 \pm 12.58(83)$ \\
& 7.24 & 1.60 & 15.71 & 8.28 & 9.98 \\
$\mathrm{~J}_{\mathrm{r}} / \mathrm{J}_{\mathrm{s}}$ & $0.18 \pm 0.06(13)$ & $0.10 \pm 0.03(8)$ & $0.20 \pm 0.05(52)$ & $0.15 \pm 0.08(19)$ & $0.18 \pm 0.06(92)$ \\
& 0.17 & 0.10 & 0.19 & 0.13 & 0.16 \\
$\mathrm{~J}_{\mathrm{n}} / \mathrm{J}_{\mathrm{a}}$ & $1.50 \pm 0.57(11)$ & $0.71 \pm 0.50(8)$ & $2.63 \pm 0.88(42)$ & $2.14 \pm 1.27(13)$ & $2.17 \pm 1.09(74)$ \\
& 1.37 & 0.58 & 2.46 & 1.73 & 1.81 \\
\hline
\end{tabular}

Note: Upper value represents arithmetic mean and the standard deviation of the individual samples; lower value represents geometric mean; values in parentheses: number of samples; $\mathrm{J}_{n}$, NRM intensity; $\mathrm{J}_{\mathrm{a}}, \mathrm{ARM}$ intensity; $\mathrm{J}_{\mathrm{r}}$, saturation remanent magnetization; $\mathrm{J}_{\mathrm{s}}$, saturation magnetization; $\mathrm{x}$, initial susceptibility; $\mathrm{Q}_{\mathrm{n}}$, Königsberger ratio.

tensities than the upper flows, which may have been caused by differences in cooling histories in these flow units. More extensive data are needed for further discussion.

NRM inclinations observed in the present study are consistent with the shipboard measurements (Bryan et al., Site 417 , this volume; Bryan et al., Site 418 , this volume). Paleomagnetic discussions are not given here.

\section{Initial Susceptibility}

The initial susceptibility of the basalt samples ranges from $0.597 \times 10^{-3} \mathrm{G} / \mathrm{Oe}$ to $4.531 \times 10^{-3} \mathrm{G} / \mathrm{Oe}$ (Figure 1e). Arithmetic and geometric means are listed in Table 2. Two breccia samples have low values of $0.874 \times 10^{-3} \mathrm{G} / \mathrm{Oe}$ (Section 29-1) and $0.146 \times 10^{-3} \mathrm{G} / \mathrm{Oe}$ (Section 42-1), respectively, and the dike sample has a value of $3.052 \times 10^{-3}$ $\mathrm{G} / \mathrm{Oe}$. The range and the mean value of the basalt samples are comparable with results from previous DSDP sites (Lowrie, 1974), except for the unusually low susceptibilities measured in basalts from the South Atlantic Ocean (Lowrie et al., 1973).

The initial susceptibilities in pillow basalts and massive flows are compared for each hole in Table 2. Basalts from Hole 417D have larger susceptibilities than those from Hole $418 \mathrm{~A}$, and massive flows have larger susceptibility than pillow basalts. Pillow basalts in Hole 418A have the largest $\mathrm{J}_{\mathrm{n}}$ and the smallest $\chi$, and massive flows in Hole $417 \mathrm{D}$ have the other extremes. It is worth noting that in the present samples the susceptibility correlates inversely with the NRM intensity. We observed a similar correlation between saturation magnetization, $\mathrm{J}_{\mathrm{s}}$, and $\mathrm{J}_{\mathrm{n}}$. Such relations between magnetic properties will be discussed later.

\section{Königsberger Ratio, Qn}

The Königsberger ratio $\mathrm{Q}_{\mathrm{n}}=\mathrm{J}_{\mathrm{n}} / \chi \mathrm{H}$ can be calculated from the NRM intensity and the initial susceptibility. In the present calculation, $\mathrm{H}=0.5 \mathrm{Oe}$ was used for the sake of simplicity instead of $\mathrm{H}=0.465 \mathrm{Oe}$, the value of the ambient geomagnetic field at Sites 417 and 418. The Königsberger ratio ranges from 0.75 to 78.04 . Arithmetic and geometric means are listed in Table 2. The values of breccia samples, 7.81 (Section 42-1) and 13.80 (Section 29-1), are not unusually small compared with the values of basalt samples.

The range and the mean of Königsberger ratios are comparable also with those of other DSDP sites. Because only four basalt samples out of 83 have $Q_{n}$ values less than 1 and about 80 per cent of the observed $\mathrm{Q}_{\mathrm{n}}$ values are higher than 5.0 , induced magnetizations in these rocks will not contribute significantly to the measured magnetic anomalies. As evident from Table 2, the basalts from Hole 418A have much larger $\mathrm{Q}_{\mathrm{n}}$ than those from Hole 417D. Basalt samples from massive flows have much smaller $\mathrm{Q}_{\mathrm{n}}$ ratios than pillow basalts in Hole $417 \mathrm{D}$, but they are comparable in Hole 418A.

\section{ARM Intensity, $\mathrm{Ja}_{\mathrm{a}}$}

The similarity of the stability of ARM and thermoremnant magnetization (TRM) is widely known (Dunlop and West, 1969; Levi, 1973). This characteristic of ARM has been used for oceanic basalts to determine the extent to which an original TRM has been retained (Park and Irving, 1970; Ade-Hall and Johnson, 1976). Gillingham and Stacey (1971) observed that the efficiency of ARM, which is defined as the intensity of ARM divided by the applied direct field, increases as magnetite grain size decreases from 174 $\mu \mathrm{m}$ to $5 \mu \mathrm{m}$. A similar behavior in TRM has been shown for magnetite grains (Parry, 1965). Increase in the ratio of the TRM efficiency to that of ARM with smaller grain size has also been observed (Levi and Merril, 1976). Although all the above observations are made on magnetite grains, similar properties seem to exist in titanomagnetite samples (Kono, in press). ARM and its relation to NRM in oceanic 

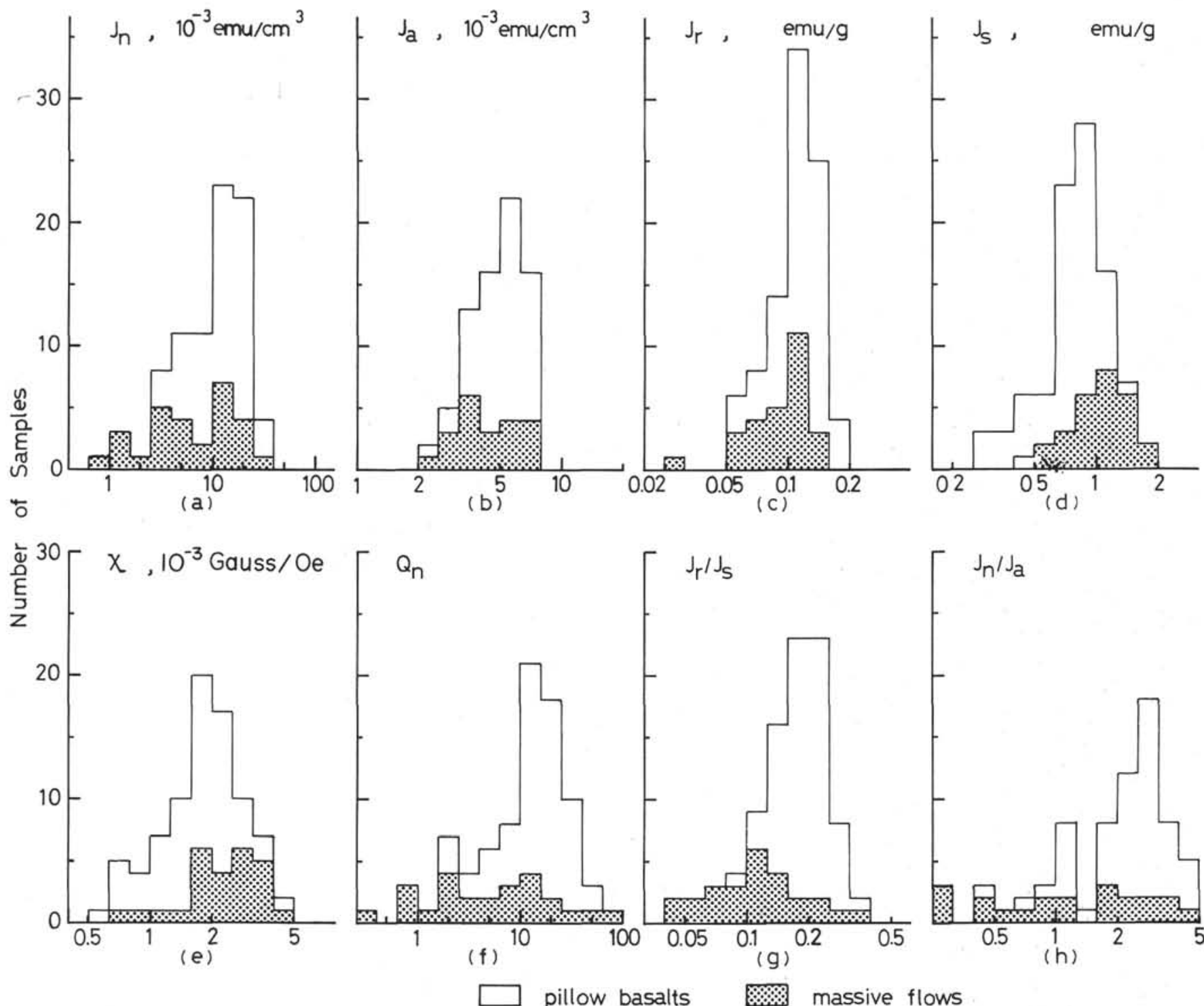

Figure 1. Histograms of magnetic properties. Basalt samples from pillows and from massive flows are compared. $J_{n}$, NRM intensity; $J_{a}, A R M$ intensity; $J_{r}$, saturation remanent magnetization; $J_{s}$, saturation magnetization; $\chi$, initial susceptibility; and $Q_{n}$, Königsberger ratio.

basalts may therefore provide information on titanomagnetites contained in these rocks. For comparison with the NRM data, the listed intensity of ARM (Tables 1 and 2) is normalized to an ambient field of 0.5 Oe by dividing the raw data by 7 , since the actual direct field used in the laboratory was $3.5 \mathrm{Oe}$. The ARM intensity ranges from $2.21 \times 10^{-3} \mathrm{emu} / \mathrm{cm}^{3}$ to $7.69 \times 10^{-3} \mathrm{emu} / \mathrm{cm}^{3}$, with an arithmetic mean of $(4.99 \pm 1.52) \times 10^{-3} \mathrm{emu} / \mathrm{cm}^{3}$ (Figure 1b). The range for the variation in ARM intensity, a factor of about 4 , is much narrower compared with that of the NRM intensity. As shown in Table 2, differences of the ARM intensity between pillow basalts and massive flows or between holes are also significant compared with those of the NRM intensity. Values of two breccia samples of 0.93 $\times 10^{-3}$ and $3.11 \times 10^{-3} \mathrm{emu} / \mathrm{cm}^{3}$, and the dike sample, of $4.96 \times 10^{-3} \mathrm{emu} / \mathrm{cm}^{3}$, are not significantly different from those of other basalt samples.

AF demagnetization curves of NRM and ARM were compared for 16 basalt samples. The relation between the mean destructive fields (MDFs) for the two remanences is shown in Figure 2. The MDF of the NRM and ARM ranges from $50 \mathrm{Oe}$ to $400 \mathrm{Oe}$, which is comparable with that of other oceanic basalts. The similarity of the MDF of the NRM and ARM suggests a comparatively simple origin for the NRM of the present samples. The ratio $\mathrm{J}_{\mathrm{n}} / \mathrm{J}_{\mathrm{a}}$ ranges from 0.25 to 5.00 with an arithmetic mean of $2.14 \pm 1.08$ (Figure 1h). Among the 74 samples measured, only 10 samples have $\mathrm{J}_{\mathrm{n}} / \mathrm{J}_{\mathrm{a}}$ values less than 1.0. The observed ratios are much larger than the average values obtained for DSDP basalts from Nazca plate by Ade-Hall and Johnson (1976). Kono (in press) observed that the ratio TRM/ARM ranged from about 1.0 to 5.0 in subaerially erupted basalts. The high values of the NRM/ARM ratio observed in the present study, in addition to similarity of the demagnetization curves of NRM and ARM, suggest that a large part of the NRM in the present basalt samples may be the original TRM component. As shown in Table 2, the ratio is higher in Hole 418A than in Hole 417D, and the pillow basalts have 


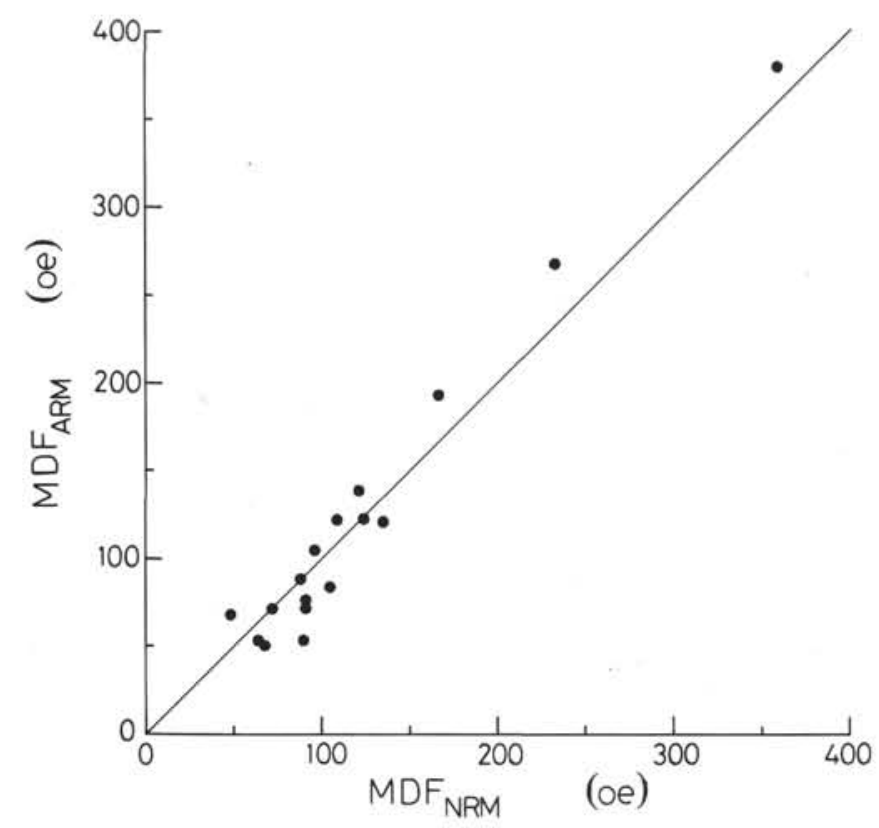

Figure 2. MDF's of NRM and ARM compared for 16 basalt samples. $M D F_{A R M}=M D F_{N R M}$ line is drawn for comparison.

higher ratios than the massive flows. One possibility is that the difference is due to grain size variation of the titanomagnetite contained in these basalt samples.

\section{Saturation Magnetization, $\mathbf{J}_{\mathrm{s}}$}

The observed saturation magnetization ranges from 0.275 to $1.915 \mathrm{emu} / \mathrm{g}$, with an arithmetic mean of $0.857 \pm 0.295$ emu/g (Figure 1d). This range is not significantly different from that observed at other DSDP sites (cf. Grommé and Mankinen, 1976; Ade-Hall et al., 1976). Table 2 indicates that the variation of $\mathrm{J}_{s}$ between pillows and massive flows is similar to that of the initial susceptibility, $\chi$. The relationship between $J_{\mathrm{s}}$ and $\chi$ is more closely shown in Figure 3 . This strong correlation is expected since, as a first approximation, both properties are determined by the amount of magnetic minerals. In the present case, the relationship also suggests a homogeneous distribution of the magnetic minerals in the basalt samples, since the initial susceptibility was measured on large samples (volume $\sim 6 \mathrm{~cm}^{3}$ ), whereas the saturation magnetization was measured on small chips $(\sim$ $0.03 \mathrm{~cm}^{3}$ ). Because of this dependence on the amount of the magnetic phase, $J_{\mathrm{s}}$ can be used to normalize $\mathrm{J}_{\mathrm{n}}$. The value of $\mathrm{J}_{\mathrm{n}} / \mathrm{J}_{\mathrm{s}}$ ranges from 0.00015 to 0.018 , and the variations of the ratio between pillows and massive flows or between holes correlate with changes in $\mathrm{Q}_{\mathrm{n}}$, which is quite reasonable considering the similarity between $\mathrm{J}_{\mathrm{s}}$ and $\chi$ shown in Figure 3 .

\section{Saturation Remanent Magnetization, $\mathbf{J}_{\mathbf{r}}$}

The observed saturation remanent magnetization ranges from 0.032 to $0.216 \mathrm{emu} / \mathrm{g}$, with an arithmetic mean of $0.138 \pm 0.038 \mathrm{emu} / \mathrm{g}$ (Figure 1c). In general, saturation remanent magnetization is a function of the magnetic mineral content and the grain size. The ratio $\mathrm{J}_{\mathrm{r}} / \mathrm{J}_{\mathrm{s}}$ is, however, considered to be a simple function of the grain size alone. Dunlop (1972) showed that the ratio increases from 0.113 to 0.289 as the grain diameter decreases from $0.22 \mu \mathrm{m}$ to

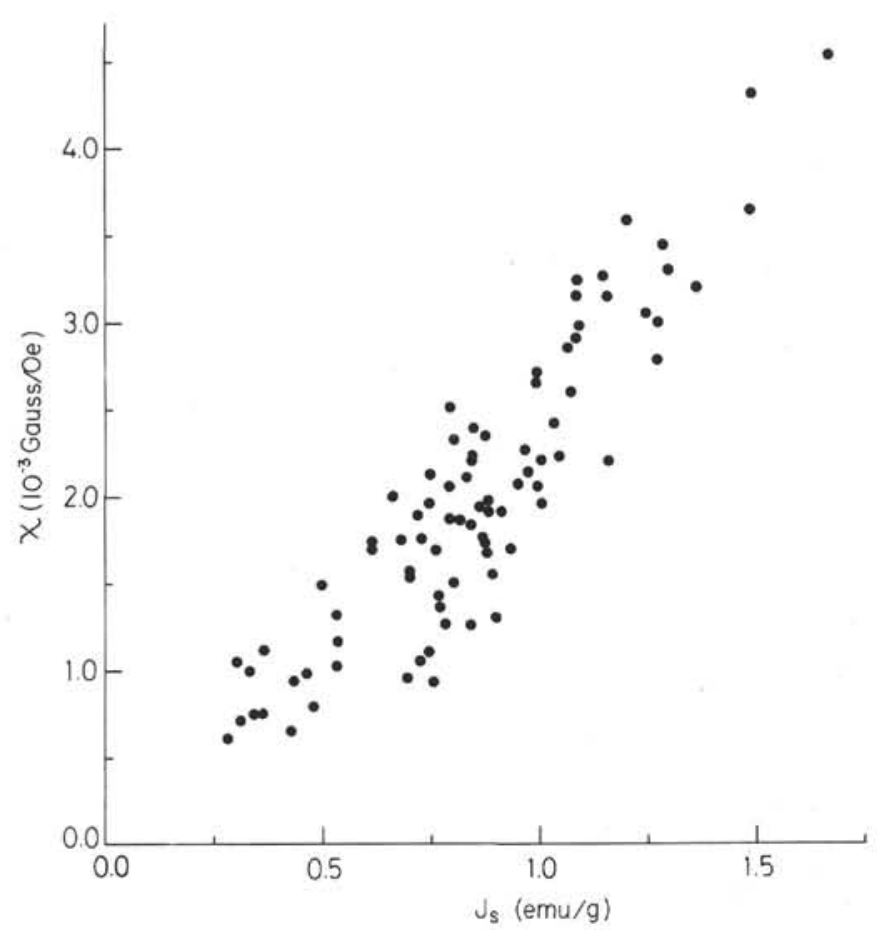

Figure 3. Relationship between initial susceptibility $(\chi)$ and saturation magnetization $\left(J_{S}\right)$ for basalts from Holes $417 D$ and $418 \mathrm{~A}$.

$0.037 \mu \mathrm{m}$ for pure magnetite grains. A similar tendency was observed by Parry (1965) for a different range of grain size. The $\mathrm{J}_{\mathrm{r}} / \mathrm{J}_{\mathrm{s}}$ ratio in the present study ranges from 0.052 to 0.318 , with an arithmetic mean of $0.175 \pm 0.063$. Pillow basalts have larger ratios than massive flows, and basalts from Hole 418A have consistently larger ratios than basalts from Hole 417D. It is a reasonable assumption that the above variation of the $\mathrm{J}_{\mathrm{r}} / \mathrm{J}_{\mathrm{s}}$ ratio is due mainly to a difference in the mean grain size. The variation of the grain size in each unit inferred from the $\mathrm{J}_{\mathrm{r}} / \mathrm{J}_{\mathrm{s}}$ ratio agrees qualitatively with the result obtained from the $\mathrm{J}_{\mathrm{n}} / \mathrm{J}_{\mathrm{a}}$ ratio in the preceding section.

\section{Thermomagnetic Curves and Curie Temperatures}

The thermomagnetic curves observed for samples from Holes 417D and 418A can be classified into the six types (Types 1 to 6) shown in Figure 4. Characteristic parameters representing each curve are summarized in Table 3 . The parameters listed are: $T_{1}$, the first Curie temperature observed during heating; $\mathrm{T}_{2}$ and $\mathrm{T}_{3}$, the highest Curie temperatures observed during heating and cooling; $\mathrm{T}_{4}$, the last Curie temperature observed during cooling and $\mathrm{J}_{\mathrm{s}}{ }^{(\mathrm{i})} / \mathrm{J}_{\mathrm{s}}{ }^{(\mathrm{f})}$, the ratio of the saturation magnetizations observed at room temperature before and after heating, respectively. Histograms of various Curie temperatures are shown in Figure 5.

$T_{1}$ is considered to be the Curie temperature of the original magnetic phase contained in the samples, while the other Curie temperatures represent new phases produced by heating. (Because of the bulge in the thermomagnetic curves during heating between $T_{1}$ and $T_{2}, T_{2}$ is not considered to represent the Curie temperature of the original phase.) The value of $\mathrm{T}_{1}$ ranges from about $200^{\circ} \mathrm{C}$ to about $440^{\circ} \mathrm{C}$ (Figure 5), with the values around $350^{\circ} \mathrm{C}$ being the 


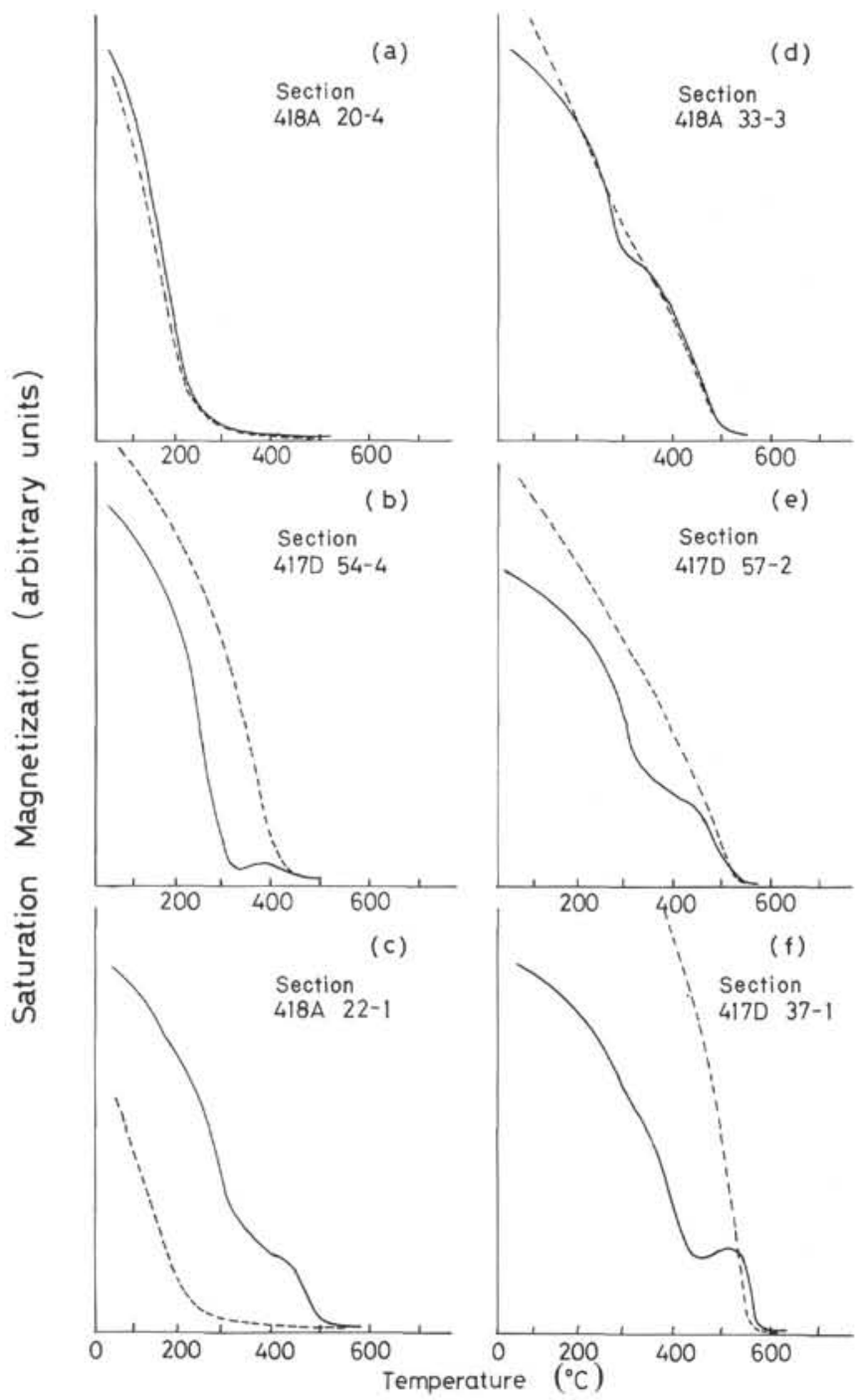

Figure 4. Main types of the thermomagnetic curves. Solid line, heating curves; dotted line, cooling curves. (a) Type 1 , nearly reversible with $T_{c} \sim 200^{\circ} \mathrm{C} ;\left(\right.$ b) Type $2, T_{c} \sim$ $300^{\circ} \mathrm{C}$; (c) Type $3, T_{c} \sim 350^{\circ} \mathrm{C}$; Curie temperature decreases in cooling process; (d) Type $4, T_{c} \sim 350^{\circ} \mathrm{C}$; (e) Type 5, $T_{C} \sim 350^{\circ} \mathrm{C}$; and (f) Type $6, T_{c} \sim 400^{\circ} \mathrm{C}$.

most abundant. The observed range of the original Curie temperatures is similar to that commonly observed in DSDP basalts and other oceanic basalts (Johnson and Hall, 1978; Marshall, 1978), and the wide distribution of the Curie temperatures is interpreted as resulting from low-temperature oxidation of stoichiometric titanomagnetite with a narrow range of composition $(\mathrm{x} \sim 0.6$, original Curie temperature $\sim 150^{\circ} \mathrm{C}$ ). Hence, the similarity of the Curie temperatures observed in the present samples with those in the previous DSDP samples indicates that the degree of lowtemperature oxidation in these samples is also similar. Since most of the previous DSDP sites that attained deep penetration into basement were located on young oceanic crust (a typical example is Site 332 which was located on basement with an age of about $3.5 \mathrm{~m}$.y.), while the basement at Sites 417 and 418 has an age of about 108 m.y., we may conclude that low-temperature oxidation of magnetic minerals in oceanic basalts occurs within a few million years after the
TABLE 3

Summary of Thermomagnetic Properties

\begin{tabular}{lccccc}
\hline $\begin{array}{l}\text { Sample } \\
\text { (Interval in cm) }\end{array}$ & $\mathrm{T}_{1}$ & $\mathrm{~T}_{2}$ & $\mathrm{~T}_{3}$ & $\mathrm{~T}_{4}$ & $\mathrm{~J}_{\mathrm{s}}^{\mathrm{i}} / \mathrm{J}$ \\
\hline Hole 417D & & & & & \\
$26-1,90-92$ & 330 & 474 & 550 & 182 & 1.02 \\
$30-5,123-126$ & 358 & 508 & & 253 & 1.03 \\
$35-5,147-149$ & 342 & 494 & 423 & & 1.06 \\
$37-5,23-25$ & & 519 & & 251 & 1.15 \\
$39-4,94-96$ & 326 & 481 & & 236 & 1.27 \\
$41-5,96-98$ & 256 & & & 164 & 1.20 \\
$43-4,144-146$ & 317 & 501 & 452 & & 0.75 \\
$45-2,32-34$ & 340 & 497 & 416 & 146 & 1.27 \\
$48-6,58-60$ & 326 & 501 & 459 & & 0.85 \\
$48-7,3-5$ & 325 & 500 & 500 & & 0.63 \\
$54-4,98-100$ & 286 & 435 & 407 & & 0.71 \\
$57-2,87-89$ & 369 & 515 & 519 & & 0.75 \\
$62-3,21-23$ & 374 & 494 & & 187 & 1.41 \\
$64-6,30-33$ & 308 & 439 & 420 & & 0.82 \\
$66-4,144-147$ & 372 & 477 & & 202 & 1.42 \\
$67-2,80-83$ & 303 & 445 & 383 & & 0.86 \\
$68-6,83-86$ & 270 & & 358 & & 1.15 \\
$69-1,100-103$ & 270 & & & 232 & 1.16
\end{tabular}

Hole $418 \mathrm{~A}$

$\begin{array}{llllll}15-1,85-88 & 303 & 443 & & 192 & 1.23\end{array}$

$\begin{array}{lllll}16-2,38-41 & 401 & 536 & 499 & 0.76\end{array}$

$\begin{array}{lllll}17-4,19-22 & 335 & 489 & 490 & 0.71\end{array}$

$\begin{array}{llllll}18-5,73-76 & 376 & 496 & 486 & 159 & 1.24\end{array}$

$\begin{array}{llll}18-6,106-109 & 321 & 192 & 1.16\end{array}$

$\begin{array}{lllll}19-3,55-59 & 280 & 492 & 256 & 1.18\end{array}$

$\begin{array}{llll}19-6,14-17 & 228 & 211 & 1.07 \\ 20-53-56 & 223 & 215 & 1.03\end{array}$

$\begin{array}{llll}20-4,53-56 & 2239 & 175 & 1.03 \\ 20-7,5-8 & 269 & 176 & 1.34\end{array}$

$\begin{array}{llllll}22-1 & 90-93 & 334 & 496 & 225 & 1.33\end{array}$

$\begin{array}{lllll}22-1,90-93 & 334 & 496 & 225 & 1.33 \\ 23-1,11-14 & 348 & 484 & 278 & 0.99\end{array}$

$\begin{array}{llllll}23-1,11-14 & 348 & 484 & & 278 & 0.99 \\ 24-1,30-33 & 336 & 503 & 470 & & 0.86\end{array}$

$\begin{array}{lllll}24-1,122-125 & 349 & 488 & 457 & 0.91\end{array}$

$\begin{array}{llllll}25-1,9-12 & 310 & 466 & 452 & 192 & 1.04\end{array}$

$\begin{array}{lllll}25-1,20-23 & 347 & 497 & 493 & 0.83 \\ 25-1,39-42 & 338 & 489 & 452 & 0.86\end{array}$

$25-1,39-42 \quad 338 \quad 489 \quad 452$

$\begin{array}{lllll}25-1,50-53 & 310 & 452 & 377 & 0.88 \\ 25-1,61-64 & 317 & 469 & 458 & 0.78\end{array}$

$\begin{array}{lllll}25-1,72-75 & 362 & 505 & 497 & 0.93\end{array}$

$\begin{array}{llllll}25-2,15-18 & 349 & 493 & 483 & 256 & 1.41\end{array}$

$\begin{array}{llllll}26-1,104-107 & 270 & 448 & 383 & & 0.79 \\ 26-46-39 & 358 & 497 & & 167 & 1.41\end{array}$

$\begin{array}{llllll}26-4,36-39 & 358 & 497 & & 167 & 1.41 \\ 27-1,41-44 & 353 & 493 & 452 & & 0.72\end{array}$

$\begin{array}{llllll}27-2,75-78 & 352 & 496 & 486 & 202 & 1.15\end{array}$

$\begin{array}{llllll}27-2,75-78 & 352 & 496 & 486 & 202 & 1.15 \\ 27-2,79-81 & 349 & 483 & & 197 & 1.31\end{array}$

$\begin{array}{llllll}30-1,16-19 & 349 & 464 & 472 & 209 & 1.11\end{array}$

$\begin{array}{llllll}33-1,39-42 & 354 & 487 & 494 & 279 & 0.97\end{array}$

$\begin{array}{llllll}33-3,122-125 & 416 & 510 & & 311 & 1.07 \\ 33-3,130-133 & 356 & 481 & 489 & & 0.85\end{array}$

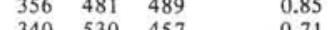

$\begin{array}{lllll}34-1,93-96 & 340 & 530 & 457 & 0.71\end{array}$

\begin{tabular}{lllllll}
\hline & 363 & 367 & 528 & 497 & 0.55
\end{tabular}

$\begin{array}{llllll}36-2,116-119 & 358 & 499 & & 154 & 1.42 \\ 36-3,31-34 & 345 & 550 & 540 & & 0.73\end{array}$

$\begin{array}{lllll}36-3,43-46 & 380 & 541 & 490 & 0.60\end{array}$

$\begin{array}{llllll}36-4,47-50 & 292 & 454 & & 209 & 1.19\end{array}$

36-4, 128-131 $380-559$ 470 0.65

$36-4,131-134 \quad 380 \quad 570 \quad 510 \quad 0.71$

$\begin{array}{lllll}37-1,46-49 & 416 & 564 & 552 & 0.47\end{array}$

$\begin{array}{llllll}38-1,54-57 & 368 & 522 & 482 & & 0.77 \\ 38-3,133-135 & 363 & 492 & & 253 & 1.06\end{array}$

$\begin{array}{llllll}38-5,99-102 & 356 & 543 & 530 & & 0.67\end{array}$

$\begin{array}{lllll}40-2,65-68 & 389 & 518 & 480 & 0.84\end{array}$

$\begin{array}{lllll}41-3,81-83 & 354 & 492 & 221 & 1.21\end{array}$

$\begin{array}{lllll}44-3,38-41 & 336 & 484 & 172 & 1.42\end{array}$

46-1, 129-132 251 $150 \quad 1.41$

$\begin{array}{llll}49-1,21-23 & 305 & 151 & 1.26\end{array}$

$50-3,130-132 \quad 265 \quad 164 \quad 1.33$

$\begin{array}{lllll}53-3,21-23 & 353 & 483 & 234 & 1.30\end{array}$

$\begin{array}{lllll}55-5,31-33 & 376 & 483 & 169 & 1.36\end{array}$

$\begin{array}{llllll}63-2,11-13 & 394 & 488 & 398 & 156 & 1.47\end{array}$

$\begin{array}{lllll}68-2,98-100 & 358 & 439 & 159 & 1.51\end{array}$

$\begin{array}{lllll}72-1,105-107 & 392 & 465 & 172 & 1.81\end{array}$

$\begin{array}{llllll}77-2,22-24 & 374 & 439 & 448 & 1.06\end{array}$

$\begin{array}{lllll}80-2,90-92 & 330 & & 146 & 1.39\end{array}$

$\begin{array}{llll}80-3,67-69 & 358 & 167 & 1.53\end{array}$

\begin{tabular}{lllll}
$84-3,137-139$ & 303 & & 152 & 1.29 \\
$86-4,108-110$ & 441 & 505 & 197 & 1.78 \\
\hline
\end{tabular}

Note: $T_{1}$, the first Curie temperatures observed during heating; $\mathrm{T}_{2}$ and $\mathrm{T}_{3}$, the highest Curie
temperatures observed during heating and cooling; $\mathrm{T}_{4}$, the last Curie temperatures observed during cooling; $\mathrm{J}_{s}^{1} / \mathrm{J}_{\mathrm{s}}^{\mathrm{f}}$, the ratio of saturation magnetizations observed at room temperature before and after heating, respectively; temperatures in ${ }^{\circ} \mathrm{C}$. 

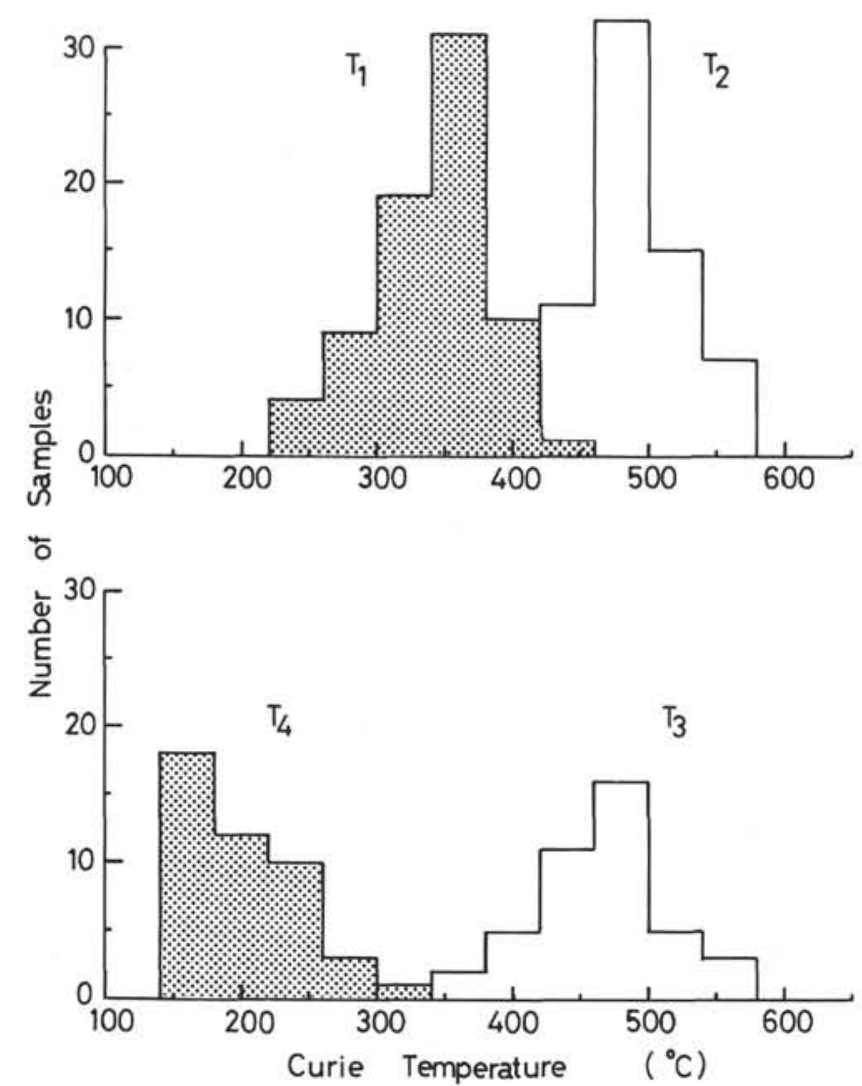

Figure 5. Histograms of the Curie temperatures. $T_{l}$, the first Curie temperature observed during heating; $T_{2}$ and $T_{3}$, the highest Curie temperatures observed during heating and cooling, respectively; and $T_{4}$, the last Curie temperature observed during cooling.

crystallization of the basement rocks. This interpretation is consistent with observations on surface rocks dredged from the floor and walls of the central rift valley along the MidAtlantic Ridge (Johnson and Atwater, 1977).

The six types of observed thermomagnetic curves are arranged in order of increasing Curie temperature, $T_{1}$. Type 1 shows approximately reversible curves with a low Curie temperature of about $200^{\circ}$. The ratio $\mathrm{J}_{s}{ }^{(\mathrm{i})} / \mathrm{J}_{s}{ }^{(\mathrm{f})}$ in this type is close to unity. Type 1 samples in the present study are very few; only two samples (Sample 418A 19-6, 14-17 cm and Sample 20-4, 53-56 cm) from a massive flow unit in Hole $418 \mathrm{~A}$ have this type of thermomagnetic curve. Types 2,4 , 5 , and 6 are typical of thermomagnetic curves for lowtemperature oxidized titanomaghemite, and have been observed in many DSDP samples and other oceanic basalts (cf. Lowrie et al., 1973; Schaeffer and Schwarz, 1970). The range of the Curie temperature $T_{1}$ in these types is from about $250^{\circ} \mathrm{C}$ to about $440^{\circ} \mathrm{C}$, while $\mathrm{T}_{2}$ and $\mathrm{T}_{3}$, the Curie temperatures of decomposed or altered phases, range from about $430^{\circ} \mathrm{C}$ to about $580^{\circ} \mathrm{C}$ (Figure 5). $\mathrm{T}_{4}$ was not clearly identified in these types. Most of the $\mathrm{J}_{s}{ }^{(\mathrm{i} /} / \mathrm{J}_{s}{ }^{(\mathrm{f})}$ ratios in these types are less than unity, and usually the ratio decreases as $\mathrm{T}_{1}$ increases.

In Type 3 samples the heating curves are similar to those of Types 5 and 6 , but the cooling curves show an apparent decrease in the Curie temperature. Because this type of thermomagnetic curve is the most abundant in the present study (Figure 5, Table 3) and has only rarely been reported in the literature (Marshall, 1978), we studied these samples in considerable detail. The result of repeated thermal cycling on a Type 3 sample is shown in Figure 6. The low Curie temperature $\left(\sim 150^{\circ} \mathrm{C}\right)$ phase increases by repeated heating. It may have some meaning that the Curie temperature of $150^{\circ} \mathrm{C}$ is that of stoichiometric titanomagnetite with $\mathrm{x}=0.6$. In Figure 7 the effect of sample size on Type 3 samples is shown, where the mean sample diameter varies from $5 \mathrm{~mm}$ to $5 \mu \mathrm{m}$. The heating curves are similar for various sample sizes, while the cooling curves vary with sample size. The decrease in the Curie temperature during cooling is more prominent for the larger samples. As the sample size decreases, the change in the Curie temperature becomes less apparent. In cases where the mean sample diameter is smaller than $100 \mu \mathrm{m}$, the thermomagnetic curves may be classified as Type 5 or 6 . A relation between sample size and curve shape was not clearly observed in other types of samples. The $J_{s}^{(i)} / J_{s}^{(f)}$ ratios in Type 3 samples are greater than, or approximately equal to, unity (Table 3 ).

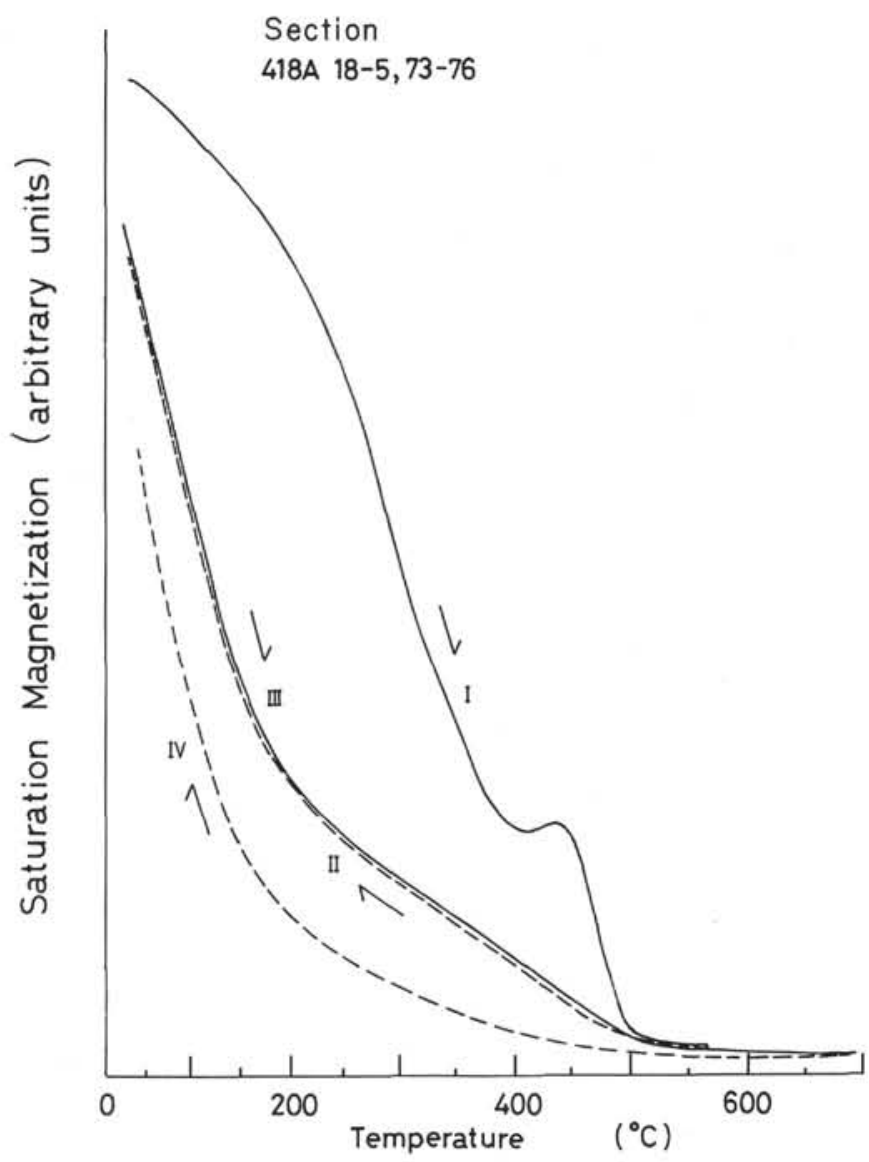

Figure 6. Example of thermomagnetic curves in repeated thermal cycling. I, the first heating; II, the first cooling; $I I I$, the second heating; and $I V$, the second cooling. Heating and cooling curves are identified by solid and dotted lines, respectively. 


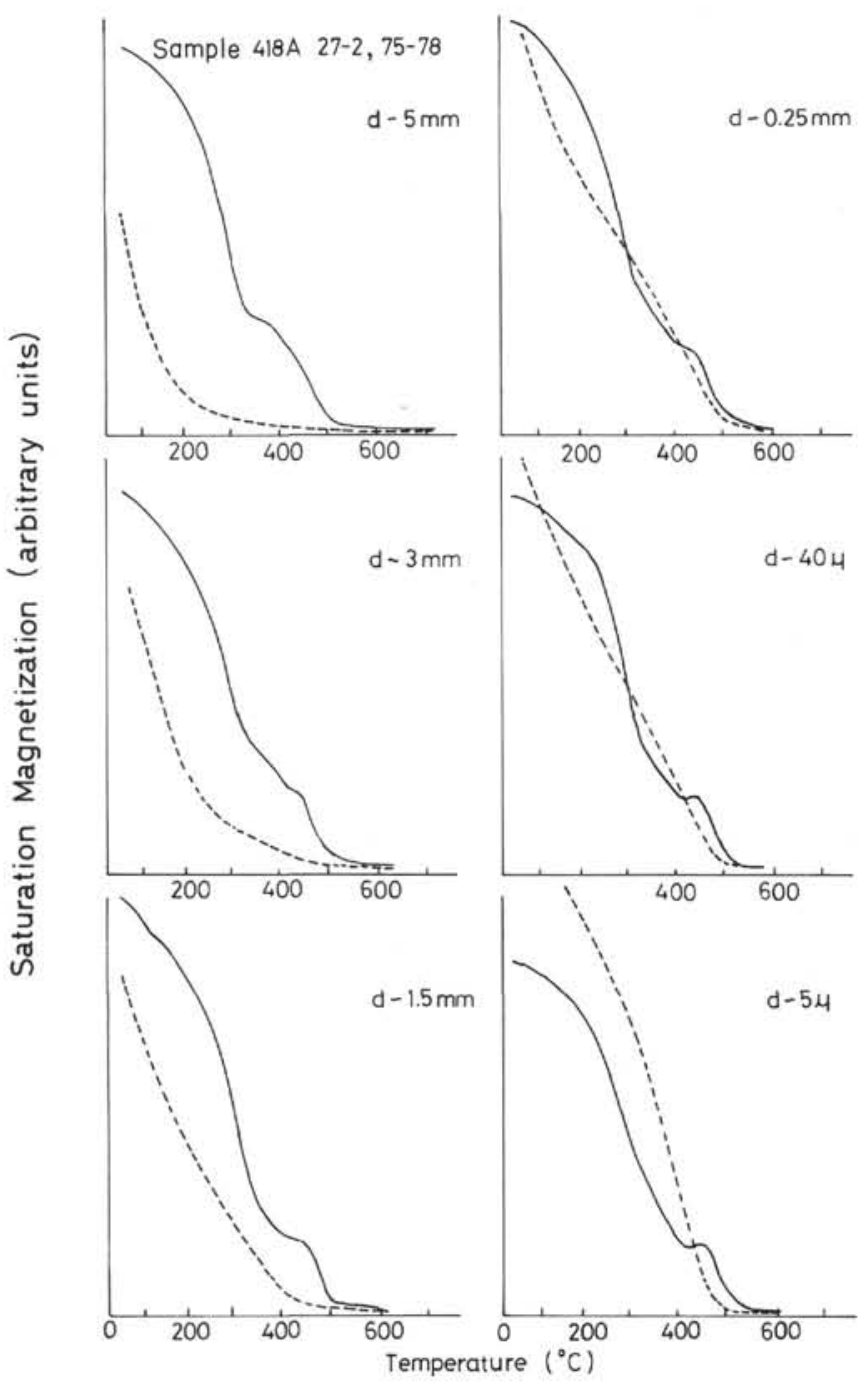

Figure 7. Variation of Type 3 thermomagnetic curves as a function of sample diameter (d) for a single specimen (Sample 418A-27-2, 75-78 cm).

These thermomagnetic curves will be interpreted later in light of the lattice constants observed for magnetic minerals separated from the samples.

\section{Lattice Constants of Magnetic Minerals}

Almost all thermomagnetic curves observed in the present study are irreversible, and it is fairly difficult to understand all of these curves by simply assuming a decomposition of thermally unstable, low-temperature oxidized titanomaghemite. Hence, to identify magnetic minerals contained in the present samples, some other information is necessary, such as the Fe/Ti ratio observed by electron microprobe analysis (Donaldson et al., 1976; Yeats et al., 1973) and lattice constants of magnetic minerals (Ozima et al., 1974; Bleil and Peterson, 1977). In the present study, the lattice constants of magnetic mineral grains from selected samples were measured by the X-ray diffraction method. Since we intend to identify secondary products during the laboratory heating as well as the original phase, the lattice-constant determinations were made also after heating.
The results are summarized in Table 4 along with the corresponding Curie temperatures, and the relation between the lattice constants and the Curie temperatures is shown in Figure 8. Also shown are low-temperature oxidation lines for synthetic stoichiometric titanomagnetites with compositions $x=0.6$ and 0.7 (Nishitani, in preparation). After separation of the magnetic minerals, the lattice constant of the minerals was determined. This lattice constant and the corresponding Curie temperature $T_{1}$ represent the original magnetic phase in each sample. Most of the data in the $T_{c}$ versus lattice constant diagram are confined between the two oxidation lines for $x=0.6$ and 0.7 . This indicates that the magnetic minerals are titanomaghemites with a narrow range of ulvöspinel content $(x=0.6 \sim 0.7)$. Some samples $(\mathrm{d}, \mathrm{m}, \mathrm{n}$, and $\mathrm{p}$ ) show considerable deviation from the above trend. Although the mechanism is not clear at present, the small $\mathrm{J}_{\mathrm{r}} / \mathrm{J}_{\mathrm{s}}$ ratios observed in these samples (see Table 1) suggest that this deviation is caused by large magnetic grain size.

\section{DISCUSSION}

\section{Changes of Magnetic Minerals During Thermomagnetic Analysis}

Irreversible thermomagnetic curves, commonly observed in oceanic basalts, indicate that magnetic minerals in these samples change during the thermomagnetic analysis. This thermal instability has been noted to be a typical characteristic of low-temperature, oxidized titanomaghemites (Ozima and Ozima, 1971). This phase in oceanic basalts has been extensively examined by electron microprobe analyses or $\mathrm{X}$-ray diffraction measurements in addition to thermomagnetic analyses. The heating products have received relatively little attention, however. In the present study, Curie temperatures and lattice constants of the magnetic minerals were obtained both before and after the thermomagnetic analysis, and they provide a good clue to the interpretation of the change of the magnetic minerals by heating.

As discussed in the preceding section, magnetic minerals originally contained in the present samples are mostly titanomaghemites $(x=0.6 \sim 0.7)$ displaying varying degrees of low-temperature oxidation, which decompose or unmix to an iron-rich stoichiometric titanomagnetite (spinel structure) and a hemo-ilmenite (rhombohedral structure) during heating in a vacuum (Ozima and Ozima, 1971). The Curie temperature observed during cooling and the lattice constant measured after heating represent the decomposed spinel phase. The data in Figure 8 indicate that the magnetic phase lie close to a stoichiometric titanomagnetite line. The phase in most of the samples, except samples d and e, are interpreted to be iron-rich titanomagnetites with $\mathrm{x}<\sim 0.3$, which can be a decomposed product of titanomaghemite, although the other phase (hemo-ilmenite) was not clearly detected by X-ray diffraction. Because the above measurements were made mainly on separated minerals, the decrease in the Curie temperature was not observed, although many samples (Samples b, c, f, i, j, m, and p) belong to Type 3. Sample e belongs to Type 1 . The change of the magnetic phase in this sample during heating, expressed in a $\mathrm{T}_{\mathrm{c}}$ versus lattice constant diagram, indicates that the original magnetic phase was a slightly oxidized titanomagnetite, and 
TABLE 4

Results of X-Ray Diffraction Measurements

\begin{tabular}{|c|c|c|c|c|}
\hline \multirow{2}{*}{$\begin{array}{c}\text { Sample } \\
\text { (Interval in } \mathrm{cm} \text { ) }\end{array}$} & $\begin{array}{c}\text { Lattice } \\
\text { Constant, }(\AA)\end{array}$ & $\begin{array}{c}\text { Curie } \\
\text { Temperature, }\left({ }^{\circ} \mathrm{C}\right)\end{array}$ & $\begin{array}{c}\text { Lattice } \\
\text { Constant, }(\AA)\end{array}$ & $\begin{array}{c}\text { Curie } \\
\text { Temperature, }\left({ }^{\circ} \mathrm{C}\right)\end{array}$ \\
\hline & \multicolumn{2}{|c|}{ (before heating) } & \multicolumn{2}{|c|}{ (after heating) } \\
\hline $417 \mathrm{D}-54-4,98-100$ & $8.4312 \pm 0.0034$ & 286 & $8.4301 \pm 0.0072$ & 392 \\
\hline $418 \mathrm{~A}-15-1,85-88$ & $8.4289 \pm 0.0019$ & 303 & $8.4282 \pm 0.0018$ & 389 \\
\hline $418 A-18-5,73-76$ & $8.4061 \pm 0.0060$ & 376 & $8.4070 \pm 0.0090$ & 488 \\
\hline $418 \mathrm{~A}-18-6,106-109$ & $8.4507 \pm 0.0012$ & 321 & $\begin{aligned} 8.4641 & \pm 0.0045 \\
(8.4710 & \pm 0.0027\end{aligned}$ & $\begin{array}{l}250 \\
192)\end{array}$ \\
\hline $418 \mathrm{~A}-20-4,53-56$ & $8.4600 \pm 0.0024$ & 223 & $8.4664 \pm 0.0028$ & 192 \\
\hline $418 \mathrm{~A}-22-1,90-93$ & $8.4122 \pm 0.0083$ & 334 & & \\
\hline $418 \mathrm{~A}-25-1,72-75$ & $8.4060 \pm 0.0061$ & 362 & $8.4109 \pm 0.0053$ & 507 \\
\hline $418 \mathrm{~A}-25-2,15-18$ & $8.3935 \pm 0.0294$ & 349 & & \\
\hline $418 \mathrm{~A}-27-2,75-78$ & $8.4045 \pm 0.0021$ & 352 & $\begin{aligned} 8.4195 & \pm 0.0047 \\
(8.4745 & \pm 0.0046\end{aligned}$ & $\begin{array}{l}465 \\
157)\end{array}$ \\
\hline $418 \mathrm{~A}-36-4,47-50$ & $8.4299 \pm 0.0017$ & 292 & $8.4286 \pm 0.0027$ & 411 \\
\hline $418 \mathrm{~A}-37-1,46-49$ & $8.3657 \pm 0.0077$ & 416 & $8.3774 \pm 0.0205$ & 548 \\
\hline $418 \mathrm{~A}-38-1,54-57$ & $8.3878 \pm 0.0026$ & 368 & & \\
\hline $418 \mathrm{~A}-55-5,31-33$ & $8.4231 \pm 0.0020$ & 376 & $8.4256 \pm 0.0015$ & 416 \\
\hline $418 \mathrm{~A}-77-2,22-24$ & $8.4245 \pm 0.0024$ & 374 & $8.4128 \pm 0.0024$ & 458 \\
\hline $418 \mathrm{~A}-16-2,38-41$ & $8.4067 \pm 0.0005$ & 390 & & \\
\hline 417D-69-1, 100-103 & $8.4577 \pm 0.0007$ & 275 & & \\
\hline
\end{tabular}

Note: Separated titanomagnetites/grains were heated in a vacuum to $700^{\circ} \mathrm{C}$. Values in parentheses from rock chips heated under the same conditions.

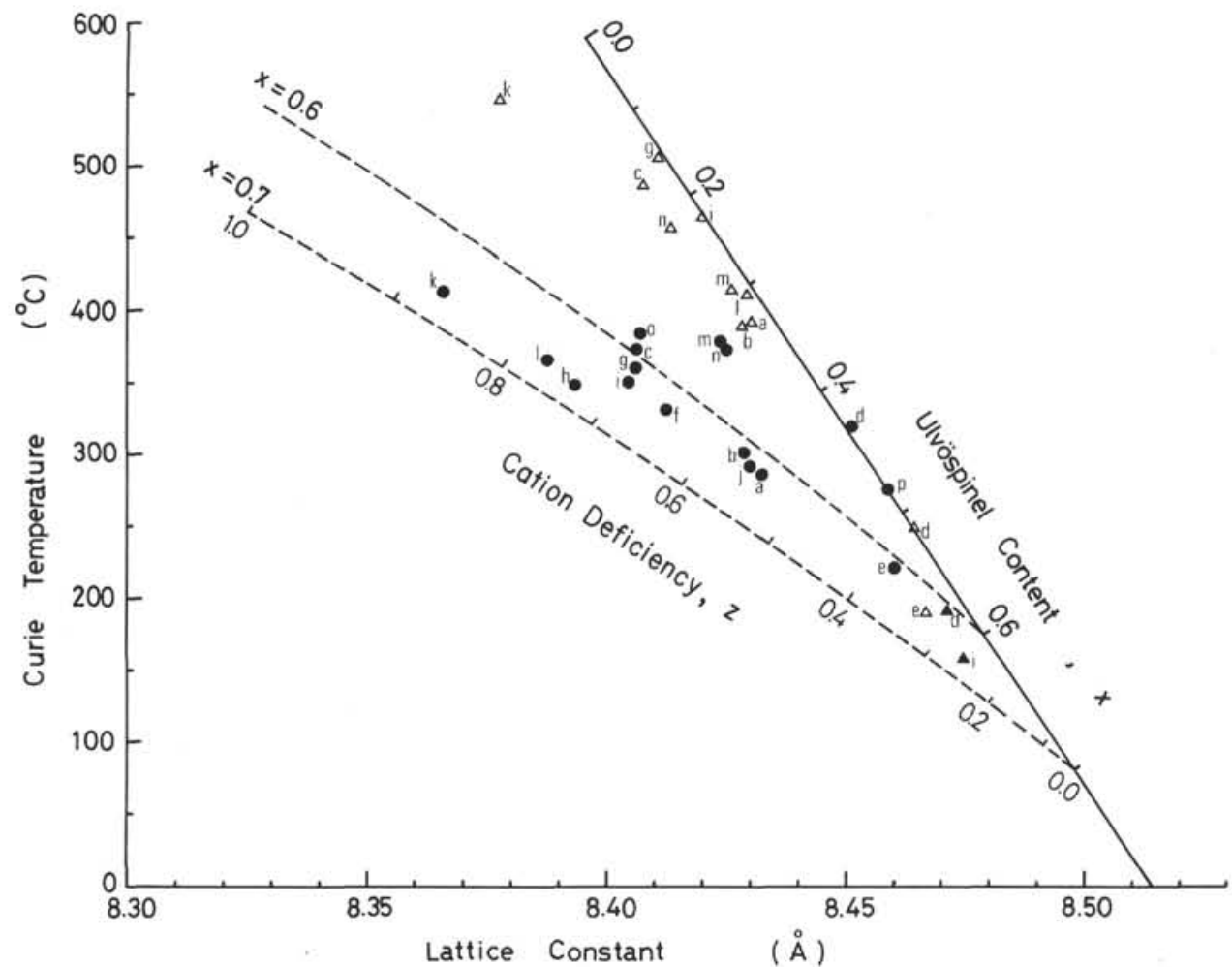

Figure 8. Relationship between Curie temperatures ( $T_{c}$ ) and lattice constants (a) for magnetic minerals in basalts from Holes $417 D$ and $418 \mathrm{~A} . \bullet$, the original magnetic phases; $\triangle$, the new products caused by heating the separated magnetic minerals to $700^{\circ} \mathrm{C}$ in a vacuum; $\mathbf{\Delta}$, the products formed when bulk rock samples $\sim \sim 100 \mathrm{mg}$ in weight) were heated under the same conditions. Sample names $a, b$, c, etc. are the same as in Table 4. 
that the phase has been reduced during heating toward a stoichiometric titanomagnetite. The thermomagnetic curve of sample $d$ is intermediate between Types 1 and 3 , in which the heating curve does not indicate decomposition of the original phase and the cooling curve shows a decrease of the Curie temperature. The data in Figure 8 indicate that the magnetic phase in sample $d$ apparently changes along a stoichiometric titanomagnetite line and toward decreasing $\mathrm{x}$. When the sample was heated in bulk (as a 100-mg chip), the change was more prominent and the phase became close to a stoichiometric titanomagnetite with $\mathrm{x}=0.6$.

The size dependence of the thermomagnetic curves is more clearly shown in Type 3 samples. In Figure 8 this is indicated by Sample i. The original magnetic phase of the sample is moderately low-temperature, oxidized titanomaghemite. Upon heating the magnetic minerals separated from the sample in a magnetic balance, the composition approached that of stoichiometric titanomagnetite with $\mathrm{x} \sim$ 0.2 . For a large sample size (about $5 \mathrm{~mm}$ in diameter), the composition approached that of stoichiometric titanomagnetite with $x \sim 0.6$, which is considered to be close to the composition of the initially crystallized titanomagnetite. Since the heating curve is similar to that in the former case and indicate the decomposition of the titanomaghemite during heating, the change of $x$ from about 0.2 to about 0.6 must have occurred while the sample was at a temperature higher than the Curie temperature of the decomposed phase. The change can be explained by reducing and mixing of the decomposed titanomagnetite $(x \sim 0.2)$ and the hemoilmenite. If this is the case, low oxygen fugacity is required during mixing. The above sample size dependence can then be understood if some buffer minerals, contained in the basalts, control the oxygen fugacity in the samples. Thus, for a large sample size, the oxygen fugacity is low owing to the buffer, whereas for a small sample size the oxygen fugacity is controlled mainly by the ambient atmosphere $(\sim$ $10^{-4}$ torr of air). In our present state of knowledge, it is not possible to determine the buffer minerals; but sulfides, which are abundant in oceanic basalts (Mathez, 1976), may be a candidate.

\section{Effect of the Cooling History on Magnetic Properties}

One of the main reasons for studying the magnetic properties of oceanic basement rocks is to understand the origin of the lineated magnetic anomalies observed at the ocean surface. For this purpose it is important to find out a dominant mechanism or mechanisms controlling the NRM intensity and other magnetic properties in the basement rocks. Recent studies have revealed the importance of lowtemperature oxidation (Johnson and Atwater, 1977; Hall, 1977). Surface samples dredged in the neighborhood of the ridge axis show a correlation of magnetic properties with both age and the degree of the low-temperature oxidation (Johnson and Atwater, 1977; Irving et al., 1970). Most of the DSDP samples, however, do not show such correlations (Johnson and Hall, 1978; Ade-Hall and Ryall, 1977). The reason might be that another mechanism (or mechanisms) contributes to the variation of the magnetic properties. The cooling rate effect during initial crystallization of the rocks may be such a mechanism. At the vicinity of a pillow surface, it has been examined (Marshall and Cox, 1971; Ryall and Ade-Hall, 1975). These studies indicate that the concentration and grain size of the magnetic minerals vary systematically within a thin surface layer $(\sim 10 \mathrm{~cm})$ in pillow basalts.

The effects of the cooling rate on the concentration and the grain diameter in samples consisting of basalts from massive flows and pillows are considered as follows (Marshall and Cox, 1971): (1) The magnetic mineral concentration increases with slower cooling until the rock is completely crystalline, beyond which it will be constant; and (2) the grain size becomes larger with slower cooling until the grains suffer high-temperature oxidation which causes a decrease in the effective grain size. But the high-temperature, oxidized phase has not been observed in the oceanic basement rocks. Thus, a positive correlation between grain size and concentration of the magnetic minerals is expected if the cooling rate effect is dominant in the rocks. Among the magnetic properties observed in the present study, the saturation magnetization, $\mathrm{J}_{\mathrm{s}}$, is the most suitable to represent the magnetic mineral concentration. For the grain size, the ratio of the saturation remanent magnetization, $\mathrm{J}_{\mathrm{r}}$, to the saturation magnetization, $\mathrm{J}_{\mathrm{s}}$, can be used as the parameter. In Figure 9, the present data are plotted in a $J_{s}$ versus $J_{r} / J_{s}$ diagram, showing a strong inverse correlation. Because these results were obtained on minicore size samples, data on samples near pillow surfaces were not initially included. To obtain data on samples with faster cooling rates, a $5-\mathrm{cm}$ long specimen (Sample 418A 46-1, 108-113 cm) with a glassy pillow surface was divided into many small chips, and measurements of $\mathrm{J}_{\mathrm{r}}$ and $\mathrm{J}_{\mathrm{s}}$ were made. Results are plot-

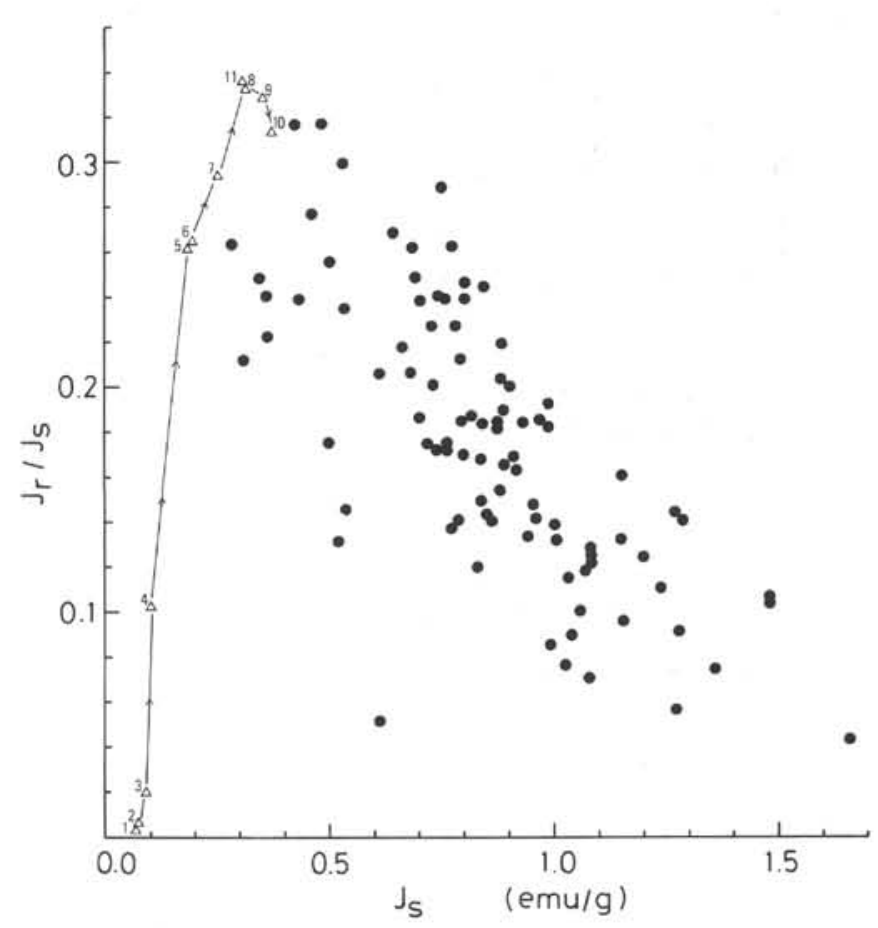

Figure 9. Variation of $J_{r} / J_{s}$ ratio with $J_{s}$ (For the meaning of symbols, see Note to Table 1.) $\bullet$, the data in the basalt samples from the interior of pillows and massive flows; and $\triangle$, the data from the pillow margin; the numbers are the same as in Table 5. 
ted in Figure 9 and listed in Table 5, where the distance of each chip from the pillow surface is given. $\mathrm{J}_{\mathrm{s}}$ in these samples are small and the $\mathrm{J}_{\mathrm{r}} / \mathrm{J}_{\mathrm{s}}$ ratios are normally correlated with the $\mathrm{J}_{\mathrm{s}}$. The overall variation of the $\mathrm{J}_{\mathrm{r}} / \mathrm{J}_{\mathrm{s}}$ ratio against $\mathrm{J}_{\mathrm{s}}$ can be interpreted in terms of differences in magnetic mineral concentration and the grain size, since the maximum $\mathrm{J}_{\mathrm{r}} / \mathrm{J}_{\mathrm{s}}$ ratio is quite high and comparable with the singledomain value of $0.5 . \mathrm{J}_{\mathrm{r}} / \mathrm{J}_{\mathrm{s}}$ initially increases rapidly as the originally superparamagnetic grains become large enough to be single domain; afterwards the ratio decreases slowly as the grains become still larger and move into pseudo-singledomain or multidomain regions.

In the foregoing discussion it was shown that the cooling history of these oceanic rocks has a notable effect on the saturation magnetization $\mathrm{J}_{\mathrm{s}}$ and the $\mathrm{J}_{\mathrm{r}} / \mathrm{J}_{\mathrm{s}}$ ratio, and that $\mathrm{J}_{\mathrm{s}}$ itself can be used to represent the cooling rate. In Figure 10, the normalized ARM intensity, $\mathrm{J}_{\mathrm{a}} / \mathrm{J}_{\mathrm{s}}$, is plotted against $\mathrm{J}_{\mathrm{s}}$, showing a strong correlation. The interesting question now is to what extent the NRM properties of the present samples have been affected by their cooling history. There are many mechanisms that control the NRM properties, even if they do not affect $\mathbf{J}_{\mathrm{s}}, \mathrm{J}_{\mathrm{r}}$, or $\mathrm{J}_{\mathrm{a}}$. Viscous remanent magnetization (VRM) and chemical remanent magnetization (CRM) acquired during the low-temperature oxidation of magnetic minerals are considered to be the dominant secondary components in the NRM of oceanic basement rocks. In the present samples some are normally magnetized and the others are reversely magnetized, and the relative importance of the VRM component, which can be inferred from the AF demagnetization curves, is variable. The degree of lowtemperature oxidation also varies among these samples. These effects may obscure a correlation between the NRM intensity and the saturation magnetization. Considering these facts, we have classified the present samples into four magnetic units. The plot of the normalized NRM intensity $J_{n} / J_{s}$ versus $J_{s}$ is shown in Figure 11 for each unit. The samples in Units 1 and 4 from Hole 417D and from the lower part of Hole 418A, respectively, are considered to have been originally reversely magnetized. The samples in Unit 2 and Unit 3 from Hole 418A have normal inclinations, where Unit 3 consists of a single, thick pillow basalt flow. As can be seen in Figure 11, the $\mathrm{J}_{\mathrm{n}} / \mathrm{J}_{\mathrm{s}}$ ratio strongly correlates with $\mathrm{J}_{\mathrm{s}}$ except in Unit 3, and the ranges of the variation

TABLE 5

$\mathbf{J}_{\mathrm{S}}$ and $\mathbf{J}_{\mathbf{r}} / \mathbf{J}_{\mathrm{S}}$ Ratio as a Function of Position in a Pillow Margin Specimen (Sample 418A-46-1, $108-113 \mathrm{~cm}$ )

\begin{tabular}{rcrc}
\hline $\begin{array}{c}\text { Chip } \\
\text { No. }\end{array}$ & $\begin{array}{c}\text { Distance from } \\
\text { Pillow Surface }(\mathrm{mm})\end{array}$ & $\mathrm{J}_{\mathrm{s}} \mathrm{emu} / \mathrm{g}$ & $\mathrm{J}_{\mathrm{r}} / \mathrm{J}_{\mathrm{s}}$ \\
\hline 1 & glass & 0.066 & 0.003 \\
2 & $0-3$ & 0.069 & 0.008 \\
3 & $3-6$ & 0.086 & 0.021 \\
4 & $9-12$ & 0.099 & 0.102 \\
5 & $13-17$ & 0.177 & 0.262 \\
6 & $15-19$ & 0.196 & 0.266 \\
7 & $26-29$ & 0.247 & 0.294 \\
8 & $30-33$ & 0.312 & 0.333 \\
9 & $35-39$ & 0.352 & 0.329 \\
10 & $41-45$ & 0.365 & 0.317 \\
11 & $46-50$ & 0.307 & 0.336 \\
\hline
\end{tabular}

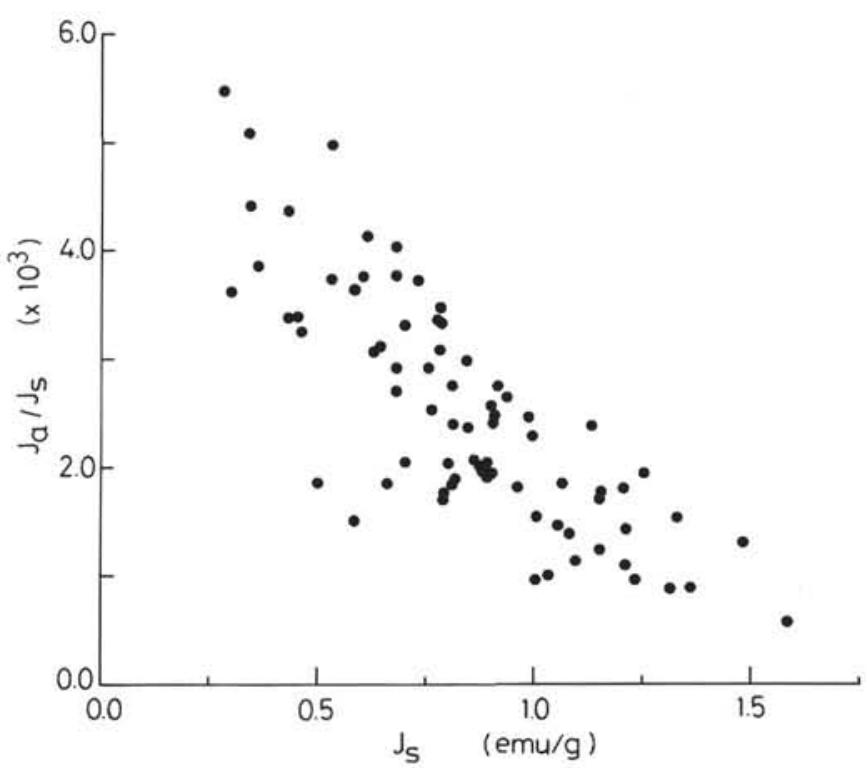

Figure 10. Variation of $J_{a} / J_{s}$ ratio with $J_{s}$ in the basalt samples. (For the meaning of symbols, see Note to Table 1.)

are much larger than that of either the $\mathrm{J}_{\mathrm{r}} / \mathrm{J}_{\mathrm{s}}$ or the $\mathrm{J}_{\mathrm{a}} / \mathrm{J}_{\mathrm{s}}$ ratio. In Unit 3 no clear correlation is observed, mainly because of scatter in the data from samples from Cores 35 through 40 . The brownish color of these latter samples suggests that alteration of basalts has a large effect on the NRM properties.

The initial cooling rate effect on the magnetic properties of the oceanic basement rocks has been emphasized; that of low-temperature oxidation of magnetic minerals also seems to affect the relation between $\mathrm{J}_{\mathrm{n}} / \mathrm{J}_{\mathrm{s}}$ and $\mathrm{J}_{\mathrm{s}}$. But the considerable influence of the initial cooling history obscures the effect of low-temperature oxidation in the relations between the magnetic properties. The scattered distribution of the variation of the magnetic properties against the Curie temperature, $T_{c}$, or the cation deficiency, $\mathrm{z}$, observed in the DSDP basalts may be attributed to this. The distinct correlations of the magnetic properties with $T_{c}$ or $z$ observed in dredge-haul basalt samples from oceanic ridge regions (Johnson and Atwater, 1977) are apparently caused by the similarity of their initial cooling history.

\section{Layer 2 Basement Rocks as the Origin of Lineated Magnetic Anomalies}

Although the oceanic Layer 2 is commonly believed to be a source region of the observed magnetic lineations, the mean thickness and intensity of the magnetized layer responsible for the anomalies are still controversial. Since the early studies by Talwani et al. (1971), the magnetized layer has been commonly assumed to be 500 meters thick in inversions of the observed magnetic anomalies (Atwater and Mudie, 1973; Herron, 1972; Pitman and Talwani, 1972). The results of these inversions suggested that the mean intensity of magnetization is about $10^{-2} \mathrm{emu} / \mathrm{cm}^{3}$ if the layer is homogeneously magnetized (Harrison, 1976). The high intensity of magnetization of the basement rocks was observed in basalt samples dredged from oceanic ridge regions or topographic highs (Lowrie, 1974; Johnson and Atwater, 


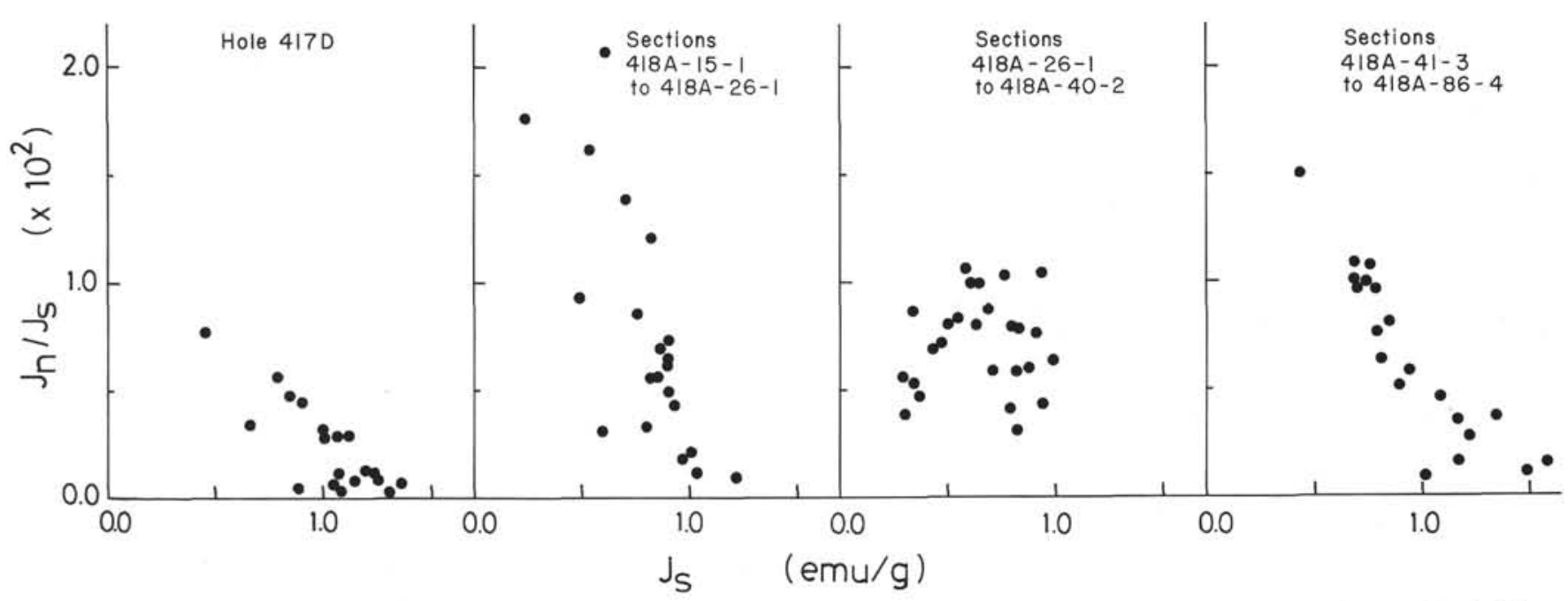

Figure 11. Variation of $J_{n} / J_{s}$ ratio with $J_{s}$ (For the meaning of symbols, see Note to Table 1.) The samples are divided into four units. Unit 1, all the samples from Hole 417D (negative stable inclinations); Unit 2, samples from Sections 418A-15-1 to 418A-26-1 (positive inclinations); Unit 3, Sections 418A-26-1 to 418A-40-2 (positive inclinations); and Unit 4, Sections 418A-41-3 to 418A-86-4 (negative inclinations).

1977). But DSDP basalt samples directly drilled from the top of Layer 2 have much smaller intensities (Lowrie, 1974; Harrison, 1976), and the deviations of the inclinations from the expected values are considerable. A larger thickness including almost all of Layer 2 is necessary, if the magnetized layer consists of such basement rocks as were previously obtained by drilling. The effect of weathering or lowtemperature oxidation of magnetic minerals has been stressed as a cause of this difference in magnetic intensities (Johnson and Atwater, 1977).

Contrary to the previous results on DSDP samples, the NRM intensities observed in the present study are very high with a mean of about $1.2 \times 10^{-2} \mathrm{emu} / \mathrm{cm}^{2}$ (Table 2), which is consistent with a 500-meter thickness for the magnetized layer. The high NRM intensitites of the basalt samples from the present sites have been confirmed by shipboard measurements on more than 400 samples (Bryan et al., Site 417, this volume; Bryan et al., Site 418 , this volume). On the other hand, other magnetic properties in the present samples are not significantly different from the previous results. In particular, the range of observed original Curie temperatures, $200^{\circ} \mathrm{C}$ to $440^{\circ} \mathrm{C}$, is very common in oceanic basalts. This indicates that it is not appropriate to attribute the difference of the NRM intensity to differences in the degree of low-temperature oxidation. In the preceding section, we have shown that the normalized NRM intensity, $\mathrm{J}_{\mathrm{n}} / \mathrm{J}_{\mathrm{s}}$, varies with the saturation magnetization $\mathrm{J}_{\mathrm{s}}$, and the correlation was interpreted as due to the effects of the initial cooling rate. In Figure 12, NRM intensities are plotted against $\mathrm{J}_{\mathrm{s}}$, where the data of Unit 3 samples are shown by squares. The diagram suggests that the NRM intensity decreases with increasing $\mathrm{J}_{\mathrm{s}}$, although the dispersion of the data is largely due to other mechanisms affecting the NRM intensity. The negative correlation between NRM intensity and $\mathrm{J}_{\mathrm{s}}$ appears strange but can be interpreted in terms of changes in magnetic mineral concentration and grain size caused by differences in cooling rate as discussed earlier. Thus, one possibility is that the variations in NRM intensitites observed between different DSDP sites are caused by differences in their initial cooling

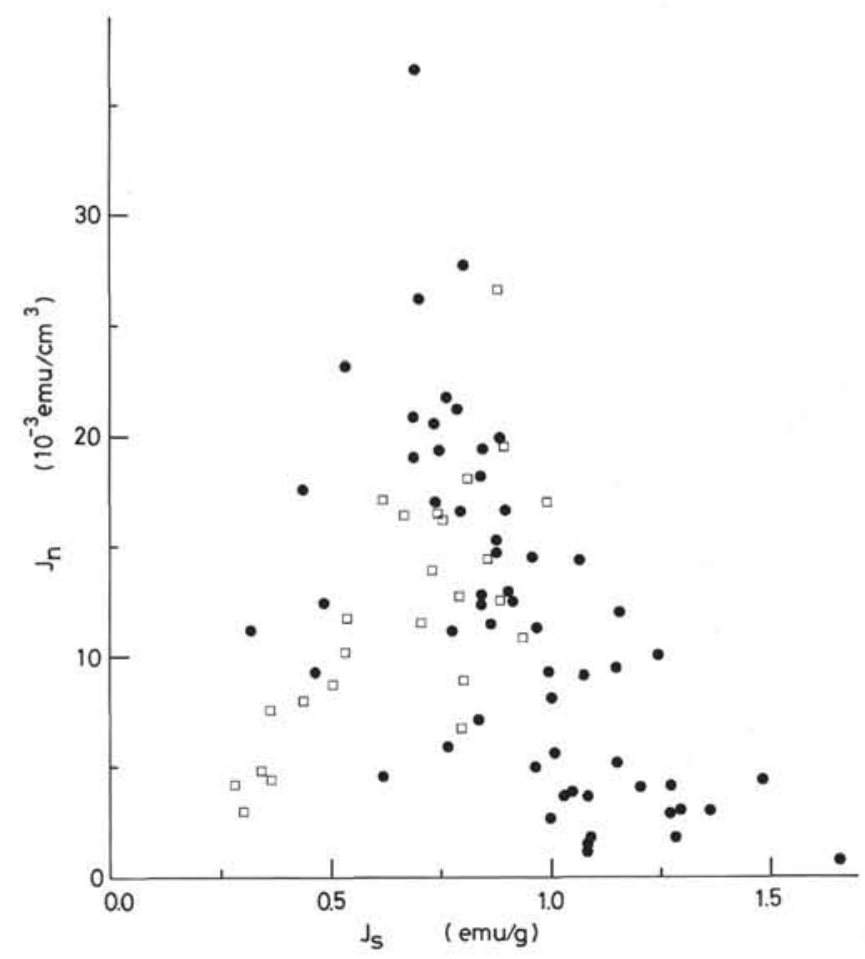

Figure 12. Dependence of NRM intensity $\left(J_{n}\right)$ on saturation magnetization $\left(J_{S}\right)$. $\bullet$, the data from Units 1,2 , and 4 in Figure 11; and $\square$, the data from Unit 3.

history. The assumptions cannot be verified at present, because not enough $\mathrm{J}_{\mathrm{r}}$ and $\mathrm{J}_{\mathrm{a}}$ data, which were useful parameters in the foregoing discussion, are available for the previous DSDP samples.

Other differences of the present samples from previous DSDP samples are: (1) The age of the basement at the present sites is about $108 \mathrm{~m}$.y., whereas most of the previous DSDP sites, where deep penetration into the basement was attained, are much younger; (2) The present basement drilled is considered to be oceanic Layer 2B, whereas most 
of the previous DSDP samples are from Layer 2A. But these differences do not explain those in NRM intensities: (1) There is no evident mechanism that increases the NRM intensity with age, while many reasonable mechanisms exist that reduce it. Thus, the old age itself cannot be a cause of the intensity difference. (2) The oceanic Layer 2 is subdivided into Layers $2 \mathrm{~A}, 2 \mathrm{~B}$, and $2 \mathrm{C}$ on the basis of seismic refraction data, and the observed in situ seismic velocity in Layer $2 \mathrm{~A}$ is much lower than that in Layer 2B (Houtz and Ewing, 1976). But seismic velocities observed in the laboratory on rock samples recovered from both layers are similar to each other (Hamano, this volume), and the mineral or chemical compositions in these samples are also not significantly different (Bryan et al., Site 417, this volume; Bryan et al., Site 418 , this volume). Therefore, the difference in NRM intensity cannot be caused by differences in rock type.

From the foregoing discussion we could not derive the mechanism(s) causing the high NRM intensities of the present samples. Measurements of magnetic properties such as $\mathrm{J}_{\mathrm{r}}$ or $\mathrm{J}_{\mathrm{s}}$ on oceanic basement rocks might be useful to clarify the mechanism controlling the NRM intensity. At present, we can say that the upper part of the oceanic basement does not always have low NRM intensities as observed in the previous DSDP sites, and that some parts of the basement have high mean intensities of more than $10^{-2} \mathrm{emu} / \mathrm{cm}^{3}$ to a depth of at least 500 meters, which is enough to explain the magnetic anomalies observed at the ocean surface.

\section{SUMMARY AND CONCLUSIONS}

Many magnetic properties were measured on basalt samples from Holes 417D and 418A located at the southwest end of the Bermuda Rise. The magnetic properties studied are the NRM intensity $\left(\mathrm{J}_{\mathrm{n}}\right)$ and inclination $\left(\mathrm{I}_{\mathrm{n}}\right)$, the ARM intensity $\left(\mathrm{J}_{\mathrm{a}}\right)$, the MDFs of the NRM and the ARM, the saturation magnetization $\left(\mathrm{J}_{\mathrm{s}}\right)$, the saturation remanent magnetization $\left(\mathrm{J}_{\mathrm{r}}\right)$, the initial susceptibility $(\chi)$, and a variety of thermomagnetic properties. The mean intensity of the NRM is fairly large (total mean of about $1.2 \times 10^{-2} \mathrm{emu} / \mathrm{cm}^{3}$ ) compared with that of previous DSDP basalt samples. The high NRM intensity is consistent with a thin $(500 \mathrm{~m})$ magnetized layer as a source for the lineated magnetic anomalies. Other magnetic properties are not significantly different from the previous DSDP results, although magnetic properties such as ARM intensity and saturation remanent magnetization have not frequently been measured on other oceanic basalts; thus, comparison with the present results is not possible. Differences exist between the magnetic properties of the pillow basalts and the massive flows, but comparable or even larger differences exist between the two holes.

Most of the thermomagnetic curves observed are irreversible types. Thermomagnetic analyses have revealed that magnetic minerals in the basalt samples are low-temperature, oxidized titanomaghemites with a Curie temperature of about $200^{\circ} \mathrm{C}$ to $440^{\circ} \mathrm{C}$. The range of Curie temperatures is comparable with that of previous DSDP basalts and other oceanic basalt samples. Thus, the high NRM intensity in the present samples cannot be attributed to a lack of low-temperature oxidation. More than half of the thermomagnetic curves on rock chip samples show an apparent decrease in the Curie temperature during heating to $700^{\circ} \mathrm{C}$ in a vacuum. The change in Curie temperature versus lattice constant diagram suggests that the newly decomposed ironrich titanomagnetites and hemo-ilmenites in these samples were reduced and mixed, approaching the composition of the initially crystallized stoichiometric titanomagnetites ( $\mathrm{x}$ $\sim 0.6$ ) during the thermomagnetic analysis. Since the decrease in the Curie temperature was not observed for a small sample size $(<100 \mu \mathrm{m})$, some buffer minerals, probably sulfides, may control the low oxygen fugacity in the basalt samples.

The observed $\mathrm{J}_{\mathrm{J}} / \mathrm{J}_{\mathrm{s}}$ ratio in the minicore samples correlates inversely with $\mathrm{J}_{\mathrm{s}}$. The data from pillow margin samples, however, showing smaller $\mathrm{J}_{s}$ and $\mathrm{J}_{\mathrm{r}} / \mathrm{J}_{\mathrm{s}}$ ratios toward the pillow surface, suggest that the variation of the magnetic properties in the basalt samples both in pillows and massive flows was strongly affected by the cooling history during initial crystallization, i.e., the data are consistent with an increase in the concentration and the grain size of the magnetic minerals with slower cooling away from the margin. A similar correlation was observed between the $J_{a} / J_{s}$ ratio and $\mathrm{J}_{\mathrm{s}}$.

The NRM intensity $\left(\mathrm{J}_{\mathrm{n}}\right)$ also seems to have been affected by the cooling rate. Not only the normalized intensity, $\mathrm{J}_{\mathrm{n}} / \mathrm{J}_{\mathrm{s}}$, but also the intensity $J_{n}$ itself shows decreasing values with increasing $\mathrm{J}_{\mathrm{s}}$, although the scatter of the data is probably due to other factors, such as VRM or CRM. At first glance this correlation seems strange because the increase in the magnetic mineral concentration apparently coincides with a decrease in the NRM intensity. Assuming that the latter effect (due to the larger grain size) overcomes the increase due to the higher concentration, we can explain the above correlation by the cooling rate effect. The high mean NRM intensities in the present samples may be attributed to the higher cooling rate at the present basement sites compared with that at previous DSDP sites. Verification of this assumption, however, should await further magnetic property data for other DSDP sites.

\section{ACKNOWLEDGMENT}

Yozo Hamano wishes to express his appreciation for the opportunity to participate on Leg 52 of the Deep Sea Drilling Project. We are grateful to Minoru Ozima for critically reading the manuscript.

\section{REFERENCES}

Ade-Hall, J. M. and Johnson, H. P., 1976. Paleomagnetism of basalts, Leg 34. In Yeats, R. S., Hart, S. R., et al., Initial Reports of the Deep Sea Drilling Project, v. 34: Washington, (U.S. Government Printing Office), p. 513-532.

Ade-Hall, J. M. and Ryall, P. J. C., 1977. Paleomagnetism of basement rocks, Leg 37. In Aumento, F., Melson, W. G., et al., Initial Reports of the Deep Sea Drilling Project, v. 37: Washington, (U.S. Government Printing Office), p. 425-445.

Ade-Hall, J. M., Johnson, H. P., and Ryall, P. J. C., 1976. Rock magnetism of basalts, Leg 34. In Yeats, R. S., Hart, S. R., et al., Initial Reports of the Deep Sea Drilling Project, v. 34: Washington, (U.S. Government Printing Office), p. 459-468.

Atwater, T. and Mudie, J. D., 1973. Detailed near-bottom geophysical study of the Gorda Rise, J. Geophys. Res., v. 78, p. 8665-8687.

Bleil, U. and Peterson, N., 1977. Magnetic properties of basement rocks, Leg 37, Site 332. In Aumento, F., Melson, W. G., et 
al., Initial Reports of the Deep Sea Drilling Project, v. 37: Washington, (U.S. Government Printing Office), p. 449-456.

Donaldson, C. H., Brown, R. W., and Reid, A. M., 1976. Petrology and chemistry of basalts from the Nazca plate: Part 1 Petrography and mineral chemistry. In Yeats, R. S., Hart, S. R., et al., Initial Reports of the Deep Sea Drilling Project, v. 34: Washington, (U.S Government Printing Office), p. 227. 238.

Dunlop, D. J., 1972. Magnetite: Behavior near the single-domain threshold, Science, v. 176, p. 41-43.

Dunlop, D. J. and West, G. F., 1969. An experimental evaluation of single domain theories, Rev. Geophys. Space Phys., v. 7, p. 709-757.

Gillingham, D. E. W. and Stacey, F. D., 1971. Anhysteretic remanent magnetization (A.R.M.) in magnetite grains, Pure Appl. Geophys., v. 91, p. 160-165.

Grommé, S. and Mankinen, E., 1976. Natural remanent magnetization, magnetic properties, and oxidation of titanomagnetite in basaltic rocks from DSDP Leg 34. In Yeats, R. S., Hart, S. R., et al., Initial Reports of the Deep Sea Drilling Project, v. 34: Washington, (U.S Government Printing Office), p. 485-494.

Hall, J. M., 1977. Does TRM occur in oceanic Layer 2 basalts?, J. Geomag. Geoelectr., v. 29, p. 411-419.

Harrison, C. G. A., 1976. Magnetization of the oceanic crust, Geophys. J. Roy. Astron. Soc., v. 47, p. 257-283.

Herron, E. M., 1972. Sea-floor spreading and the Cenozoic history of the East-Central Pacific, Geol.Soc. Am. Bull., v. 83, p. 1671-1692.

Houtz, R. and Ewing, J., 1976. Upper crustal structure as a function of plate age, J. Geophys. Res., v. 81, p. 2490-2498.

Irving, E., Park, J. K., Haggerty, S. E., Aumento, F., and Loncarevic, B., 1970. Magnetism and opaque mineralogy of basalts from the Mid-Atlantic Ridge at $45^{\circ} \mathrm{N}$, Nature, v. 228 , p. 974-976.

Johnson, H. P. and Atwater, T., 1977. Magnetic study of basalts from the Mid-Atlantic Ridge, lat $37^{\circ} \mathrm{N}$, Geol. Soc. Am. Bull., v. 88 , p. $541-555$.

Johnson, H. P. and Hall, J. M., 1978. A detailed rock magnetic and opaque mineralogy study of the basalts from the Nazca plate, Geophys. J. Roy. Astron. Soc., v. 52, p. 45-64.

Kono, M., in press. Reliability of paleointensity methods using alternating field demagnetization and anhysteretic remanence, Geophys. J. Roy. Astron. Soc., v. 54.

Levi, S., 1973. Comparison of some ARM and TRM properties in magnetites, Am. Geophys. Union Trans., v. 54, p. 1071.
Levi, S. and Merril, R., 1976. A comparison of ARM and TRM in magnetite, Earth Planet. Sci. Lett., v. 32, p. 171-184.

Lowrie, W., 1974. Oceanic basalt magnetic properties and the Vine and Matthews hypothesis, J. Geophys., v. 40, p. 513536.

Lowrie, W., Løvlie, R., and Opdyke, N. D., 1973. Magnetic properties of Deep-Sea Drilling Project basalts from the North Pacific Ocean, J. Geophys. Res., v. 78, p. 7647-7660.

Marshall, M., 1978. The magnetic properties of some DSDP basalts from the North Pacific and inferences for Pacific plate tectonics, J. Geophys. Res., v. 83, p. 289-308.

Marshall, M. and Cox, A., 1971. Magnetism of pillow basalts and their petrology, Geol. Soc. Am. Bull., v. 82, p. 537-552.

Mathez, E. A., 1976. Sulfur solubility and magnetic sulfides in submarine basalt glass, J. Geophys. Res., v. 81, p. 4269-4276.

Ozima, M. and Ozima, M., 1971. Characteristic thermomagnetic curve in submarine basalts. J. Geophys. Res., v. 76, p. 20512056.

Ozima, M., Joshima, M., and Kinoshita, H., 1974. Magnetic properties of submarine basalts and the implications on the structure of the oceanic crust, J. Geomag. Geoelect. v. 26, p. 335-354.

Park, J. K. and Irving, E., 1970. The Mid-Atlantic Ridge near $45^{\circ} \mathrm{N}$. Coercivity, secondary magnetization, polarity, and thermal stability of dredge samples, Canadian J. Earth Sci., v. 7, p. 1499-1514.

Parry, L. C., 1965. Magnetic properties of dispersed magnetite powders, Phil. Mag., v. 11, p. 303-312.

Pitman, W. C. and Talwani, M., 1972. Sea floor spreading in the North Atlantic, Geol. Soc. Am. Bull., v. 83, p. 619-646.

Ryall, P. J. C. and Ade-Hall, J. M., 1975. Radial variation of magnetic properties in submarine pillow basalts, Canadian $J$. Earth Sci., v. 12, p. 1959-1969.

Schaeffer, R. M. and Schwarz, E. J., 1970. The Mid-Atlantic Ridge near $45^{\circ} \mathrm{N}$ IX. Thermomagnetics of dredged samples of igneous rocks, Canadian J. Earth Sci., v. 7, p. 268-273.

Talwani, M., Windisch, C. C., and Langseth, M. G., 1971. Reykjanes ridge crest: a detailed geophysical study, J. Geophys. Res., v. 76, p. 473-517.

Yeats, R. S., Forbes, W. C., Heath, G. R., and Scheidegger, K. E., 1973. Petrology and geochemistry of DSDP, Leg 16 basalt, Eastern Equatorial Pacific. In Van Andel, T. H., Heath, G. R., et al., Initial Reports of the Deep Sea Drilling Project, v. 16: Washington, (U.S. Government Printing Office), p. 617-640. 